\title{
The Exclusionary Rule and Deterrence: An Empirical Study of Chicago Narcotics Officers $\dagger$
}

\begin{abstract}
[T]he history of the suppression doctrine demonstrates that it is both conceptually sterile and practically ineffective in accomplishing its stated objective. ... Some clear demonstration of the benefits and effectiveness of the exclusionary rule is required to justify it in view of the high price it extracts from society-the release of countless guilty criminals.
\end{abstract}

Chief Justice Warren Burger, dissenting in Bivens v. Six Unknown Fed. Narcotics Agents, 403 U.S. 388, 415 (1971).

I would not do anything to the exclusionary rule. In my personal opinion it is not a detriment to police work. In fact the opposite is true. It makes the police department more professional. It enforces appropriate standards of behavior. Throughout this police department, the majority of cases are not hurt by the exclusionary rule. ... In this unit, seldom if ever does the law of search and seizure keep us from making the searches we should be able to make.

Commander John Ryle, Head of the Narcotics Section of the Organized Crime Division of the Chicago Police Department, interview on June 6, 1986.

The exclusionary rule is one of the most controversial and divisive issues in American constitutional law. Since the rule was first applied to the states in $1961,{ }^{1}$ questions of its constitutional pedigree, its purpose, and its effectiveness have sharply divided scholars and jurists and inspired extensive political debate. ${ }^{2}$

In the last decade, the Supreme Court increasingly has fo-

† I would like to thank Chicago Superintendent of Police Rudy Nimocks for facilitating this project and Commander John Ryle and Sergeant John Killacky of the Narcotics Section of the Organized Crime Division of the Chicago Police Department, both of whom were very patient with my continued requests for information and documentation and with my constantly being underfoot. Finally, I would also like to thank the officers of the Narcotics Section for their cooperation and patience.

All of the police department documents cited in this comment are on file with The University of Chicago Law Review.

1 Mapp v. Ohio, 367 U.S. 643 (1961).

2132 Cong. Rec. H6693 (daily ed. Sept. 11, 1986 (noting proposed amendment - eventually rejected in conference - to the Omnibus Crime Control Act that would have established an across-the-board "good faith" exception to the exclusionary rule). 
cused on a single question in evaluating the rule: does the exclusionary rule deter unlawful police behavior? In United States $v$. Calandra ${ }^{3}$ and three times since, the Court has constricted the scope of the rule, basing its decisions in part on a lack of convincing empirical evidence of the rule's deterrent effect. ${ }^{4}$ Although several researchers have undertaken empirical studies of the issue, none has yet provided persuasive evidence that the rule deters unlawful searches and seizures. ${ }^{5}$

This study-based on extensive, structured interviews with Chicago narcotics officers-documents the exclusionary rule's significant deterrent effects. On an institutional level, the rule has changed police, prosecutorial, and judicial procedures; on an individual level, it has educated police officers in the requirements of the fourth amendment and has punished them when they have violated those requirements.

Section I summarizes recent Supreme Court cases that have cast doubt on the deterrent effect of the exclusionary rule; section II reviews the empirical literature on the issue of deterrence. Section III then sets forth the survey's methodology and describes how the exclusionary rule has acted as a strong institutional deterrent, prompting the police department, the state's attorney's office, and the local narcotics courts to develop programs and procedures designed to ensure compliance with the fourth amendment. Section IV describes police perceptions of the effect of the exclusionary rule on police work and the potential effect of an alternative tort remedy.

In summary, Chicago's narcotics officers are virtually always in court when evidence is suppressed in their cases; they always eventually understand why the evidence was suppressed; and this experience has caused them to use warrants more often and to exercise

3 414 U.S. 338 (1974) (declining to apply the exclusionary rule in grand jury proceedings).

4 See United States v. Janis, 428 U.S. 433 (1976); Stone v. Powell, 428 U.S. 465 (1976); United States v. Leon, 468 U.S. 897 (1984). In addition, in Elkins v. United States, 364 U.S. 206 (1960), the Court noted the dearth of empirical evidence regarding the deterrent effect of the exclusionary rule on police behavior. Individual members of the Court have made this observation regarding the deterrent effect of the rule in Coolidge v. New Hampshire, 403 U.S. 443 (1971); Bivens v Six Unknown Fed. Narcotics Agents, 403 U.S. 388 (1971); Stone, 428 U.S. 465; and Leon, 468 U.S. 897.

- See generally Dallin H. Oaks, Studying the Exclusionary Rule in Search and Seizure, 37 U. Chi. L. Rev. 665 (1970); James E. Spiotto, Search and Seizure: An Empirical Study of the Exclusionary Rule and Its Alternatives, 2 J. Legal Stud. 243 (1973); Bradley C. Cannon, Is the Exclusionary Rule in Failing Health? Some New Data and a Plea Against a Precipitous Conclusion, $62 \mathrm{Ky}$. L. J. 681 (1973-74). 
more care when conducting warrantless searches. The study also demonstrates that judicial suppression, and the actions that police officials take in response to suppression, "punish" officers for conducting illegal searches. And although in-court police perjury clearly exists in Chicago and impedes the deterrent effect of the exclusionary rule, strong institutional responses to perjury by the courts and the police department have significantly reduced the impact of perjury on the practical operation of the rule. Finally, all of the officers concluded that the exclusionary rule should be retained, albeit with a good faith exception; they generally saw the rule as a positive development and believed an alternative tort remedy would "overdeter" the police in their search and seizure activities.

\section{Case Law: The NeEd for Empirical Evidence}

In Mapp $v$. Ohio, ${ }^{6}$ the Court identified three bases for the exclusionary rule: the Court's understanding of the Constitution, considerations of "judicial integrity," and the need to deter constitutional violations. "The deterrence rationale was explained in $E l$ kins $v$. United States: "[T] repair. Its purpose is to deter-to compel respect for the constitutional guarantee in the only effective way-by removing the incentive to disregard it."

With its 1974 decision in Calandra, however, the Court began to limit application of the exclusionary rule primarily because it was skeptical about the rule's deterrent effect in particular situations. Largely abandoning the other bases for exclusion, Calandra emphasized that "the rule's prime purpose is to deter future unlawful police conduct and thereby effectuate the guarantee of the Fourth Amendment against unreasonable searches and seizures." The opinion weighed the costs of exclusion in a particular context-the loss of highly probative evidence-against the likely benefits-increased deterrence of unlawful police behavior. ${ }^{9}$ In several subsequent cases applying this cost-benefit analysis, the Court has refused to extend the exclusionary rule, ${ }^{10}$ emphasizing the lack of

${ }^{6} 367$ U.S. 643 (1961).

? Id. at $648-49,659,656$.

364 U.S. 206, 217 (1960). Elkins was decided one term prior to Mapp under the federal exclusionary rule, which had been established by the Court's decisions in Boyd v. United States, 116 U.S. 616 (1886), and Weeks v. United States, 232 U.S. 383 (1914).

9414 U.S. at $348,349-52$.

${ }^{10}$ See, e.g., Janis, 428 U.S. 433 (refusing to apply exclusionary rule in federal civil tax proceeding); Powell, 428 U.S. 465 (refusing to grant habeas relief to relitigate state court 
empirical proof of the rule's effects. ${ }^{11}$

Indeed, the "good faith" exception announced recently in United States v. Leon ${ }^{12}$ and Massachusetts $v$. Sheppard ${ }^{13}$ used Calandra's balancing formula to narrow existing applications of the rule. In Leon, the Court held that the exclusionary rule would no longer bar the use, in the prosecution's case in chief, of evidence obtained by an officer acting in reasonable, good faith reliance on a search warrant ultimately found unsupported by probable cause. Leon asserted that the sole function of the exclusionary rule is to discourage unlawful police behavior, and it found no evidence that the threat of suppression deterred magistrates or judges from improperly issuing warrants. ${ }^{14}$ It now appears that only powerful evidence of the rule's deterrent effect will save it from further dilution.

\section{The Deterrent Effect of The Exclusionary Rule}

\section{A. Summary of the Empirical Studies}

Soon after Mapp, an initial wave of empirical research examined the effect of the exclusionary rule on police behavior. Although justifiably criticized as subjective and based on unrepresentative pools of respondents, these surveys of judges, prosecutors, police officials, and public defenders revealed "a strong impression" among those closest to the operation of the exclusionary rule that, at least in some areas of the country, it caused police officers to adhere more closely to the requirements of the fourth amendment. ${ }^{15}$

denial of prisoner's suppression motion).

"See, e.g., Janis, 428 U.S. at 450 \& n.22 (" $[N]$ o empirical researcher, proponent or opponent of the rule, has yet been able to establish with any assurance whether the rule has a deterrent effect even in the situations in which it is now applied."); Powell, 428 U.S. at 492 $\&$ n.32 ("[T]he efficacy of the exclusionary rule has long been the subject of sharp debate. Until recently scholarly empirical research was unavailable. . . . And evidence derived from recent empirical research is still inconclusive."). For a sharper critique and a demand for empirical evidence of the rule's deterrent effect, see Chief Justice Burger's concurrence in Powell, id. at 496-98.

${ }^{12} 468$ U.S. 897 (1984).

13468 U.S. $981,987-88$ (1984).

14 Leon, 468 U.S. at 916,918 . In dismissing previous studies that have suggested the costs of the exclusionary rule are insubstantial, the Court asserted that "the small percentages with which they deal mask a large absolute number of felons who are released because the cases against them were based in part on illegal searches and seizures. . . . Because we find that the rule can have no substantial deterrent effect in the sort of situations under consideration in this case ... we conclude that it cannot pay its way in those situations." Id. at 907-08 n.6.

${ }^{18}$ See Stuart S. Nagel, Testing the Effects of Excluding Illegally Seized Evidence, 1965 
Later studies concluded (without firm empirical basis) that the exclusionary rule inhibited police in investigations aimed at conviction but was ineffective in other situations such as those in which searches were undertaken to confiscate contraband, recover stolen property, or assert police presence. ${ }^{16}$ These studies also reported that officers lied in court to prevent the supression of evidence. ${ }^{17}$

In the early 1970 s, three major empirical studies examined the exclusionary rule's deterrent effects. The first, by Dallin Oaks, concluded that the rule had little or no effect on the number of arrests or on the amount of stolen property recovered by the police in Cincinnati. Oaks also noted that in Chicago and Washington, the suppression of evidence occurred primarily in narcotics, gambling, and concealed weapons cases, which together represented a very small percentage of total crimes. ${ }^{18}$

Focusing on the same three high-suppression crimes in Chicago, James Spiotto tracked changes in the number of suppression motions between 1950 and $1971 .{ }^{19}$ Though this study revealed little about the deterrent effect of the exclusionary rule, ${ }^{20}$ it showed that

Wis. L. Rev. 283; Michael Katz, The Supreme Court and the States: An Inquiry into Mapp v. Ohio in North Carolina: The Model, The Study, and The Implications, 45 N.C. L. Rev. 119 (1966); Jack B. Weinstein, Local Responsibility for Improvement of Search and Seizure Practices, 34 Rocky Mt. L. Rev. 150 (1962).

16 Jerome H. Skolnick, Justice Without Trial 224-25, 228 (1967). For studies that tend to confirm Skolnick's findings, see Comment, Effect of Mapp v. Ohio on Police Search-andSeizure Practices in Narcotics Cases, 4 Colum. J. L. \& Soc. Prob. 87 (1968); Wayne R. LaFave and Frank J. Remington, Controlling the Police: The Judge's Role in Making and Reviewing Law Enforcement Decisions, 63 Mich. L. Rev. 987, 1005 (1965); Wayne R. LaFave, Improving Police Performance Through the Exclusionary Rule-Part I: Current Police and Local Court Practices, 30 Mo. L. Rev. 391 (1965).

${ }^{17}$ See, e.g., Skolnick, Justice Without Trial at 215 (cited in note 16); Comment, 4 Colum. J. L. \& Soc. Prob. at 94-95 (cited in note 16) (noting officers' frequent use of rehearsed or "pat" justifications for searches).

${ }^{18}$ Oaks, 37 U. Chi. L. Rev. at 689-96, 681-82 (cited in note 5). Oaks noted that people held for prosecution on charges of narcotics, gambling, and concealed weapons accounted for only 2 percent of the total number of defendants nationwide. Id. at 681 . Observing a particularly high rate of suppression in these cases in Chicago and noting that the rule did not appear to affect the number of police arrests in Cincinnati, Oaks argued that the rule did not have a deterrent effect. Id. at 706-07. But he admitted that his findings "obviously fall short of an empirical substantiation or refutation of the deterrent effect of the exclusionary rule." Id. at 709.

10 Spiotto, $2 \mathrm{~J}$. Legal Stud. at 243 (cited in note 5).

${ }^{20}$ Spiotto failed to take account of the fact that the exclusionary rule had been introduced in Illinois in 1923. His findings also assumed that successful motions to suppress are good measures of the underlying police behavior. But there are at least two reasons why motions to suppress do not reflect the general legality of police practices: (1) the searches that lead to motions to suppress represent only a very small percentage of searches made and (2) the availability and quality of defense counsel plays a role in the success of the 
the percentage of successful suppression motions declined in gambling and weapons cases while rising enormously in narcotics cases during the period studied. ${ }^{21}$ These disparate success rates may be explained by the efforts of judges to control dramatically increased narcotics case loads, ${ }^{22}$ composed largely of misdemeanor possession offenses, ${ }^{28}$ and the Cook County judges' use of suppression as a tool of leniency for relatively minor offenders. ${ }^{24}$

A third major study, by Bradley Cannon, replicated Oaks's Cincinnati research in thirteen other cities and showed that the effect of the exclusionary rule in Cincinnati was not typical: several other cities had experienced a significant decline in the number of arrests in the wake of Mapp, suggesting that the exclusionary rule may have had a more significant impact in terms of this indicator in other areas of the country. Cannon surveyed prosecutors and police officials regarding the level of search warrant use and the incidence of successful motions to suppress since Mapp. He reported that prosecutors and police believed there had been a significant increase in the level of search warrant use and in the number of motions to suppress. Further, the responses indicated that post-Mapp police policies had restricted the use of searches incident to arrest. ${ }^{25}$ Nevertheless, Cannon failed to prove the extent to which the exclusionary rule was responsible for these changes, ${ }^{26}$ and the poor response rate to his questionnaire may have resulted in an unrepresentative, self-selected sample. ${ }^{27}$

motion. See Critique, On the Limitations of Empirical Evaluations of the Exclusionary Rule: A Critique of the Spiotto Research and United States v. Calandra, 69 Nw. U. L. Rev. 740,744 (1974).

21 Spiotto, 2 J. Legal Stud. at 247.

${ }^{22}$ See Oaks, $37 \mathrm{U}$. Chi. L. Rev. at 685 (finding that narcotics cases increased by fifty times between 1950 and 1971 while the capacity of the narcotics courts increased only threefold).

${ }^{23}$ For example, in 1971 approximately half of the narcotics case suppressions involved misdemeanor marijuana violations, many of these involving younger, first-time offenders. Spiotto, 2 J. Legal Stud. at 264-65. Commander Ryle says that one of the major reasons why so much evidence was suppressed in the late 1960's was that judges used the exclusionary rule as a safety valve in an overcrowded and overworked court system. "There was a tremendous growth in the drug culture in the mid-60's and a lot more drugs on the street. The courts were suddenly flooded with more cases than they could handle. The pressure of numbers was a controlling factor and in the mid-60's evidence started to be thrown out in response." Interview, June 6, 1986. Sergeant John Killacky noted that a great percentage of these cases that were being thrown out involved "white kids from the suburbs" that judges did not want to send to jail. Interview, March 1986.

34 Spiotto, 2 J. Legal Stud. at 252.

${ }^{25}$ Cannon, $62 \mathrm{Ky}$. L. J. at 703-07, 707-16, 717-25, 716-17

${ }^{28}$ Id. at 714.

${ }^{27}$ See Steven R. Schlesinger, The Exclusionary Rule: Have Proponents Proven That It 
In sum, though the extant empirical research neither proves nor disproves the inhibitory effect of the exclusionary rule, the response-based literature together with the decline in suppression rates in non-narcotic cases in Chicago tentatively suggest that the exclusionary rule has had some deterrent effect in some parts of the country. ${ }^{28}$ More importantly, the studies provide vital sociological and descriptive data concerning the operation of the rule in practice. Knowledge of such things as police perjury, the ineffectiveness of the rule in searches not aimed at securing convictions, and the concentration of the rule's effects in a few areas comprising a very small percentage of total crimes, is extremely important in understanding the rule in practice.

\section{B. The Critics of the Exclusionary Rule}

Based on the foregoing research and on their own inductive analysis, critics of the exclusionary rule-both members of the Court and leading academics-have vigorously asserted several reasons why the exclusionary rule cannot operate as an effective deterrent. First, they argue, the institutional structure and norms of the criminal justice system undermine the rule's effectiveness. The rule's sanction-suppression of evidence, possibly resulting in loss of a conviction-affects the prosecutor's office and the police department as a whole, not the individual officer. ${ }^{29}$ Moreover, it is argued, police superiors are unconcerned with suppressions and are likely to encourage or at least accept illegal behavior. ${ }^{30}$

Second, critics maintain, suppression hearings are confusing and unproductive experiences for the police and thus fail to instruct them in correct search behavior. ${ }^{31}$ Specifically, opponents maintain that (1) the police often do not understand rulings in court; (2) prosecutors seldom adequately explain why evidence is

Is a Deterrent to Police?, 62 Judicature 404, 406-08 (1979).

28 Oaks himself notes that "though clearly insufficient to justify a firm conclusion on the matter, there is some evidence that: (a) Police training in search and seizure rules is more extensive where there is an exclusionary rule; (b) Police adherence to legality in searches was thought to have increased generally after the Mapp decision, with the proportion of perceived increase in states that Mapp had forced to adopt the exclusionary rule being larger than the increase in states that had the rule all along; (c) Police effectiveness in searches was perceived to have decreased more in states that had just adopted the exclusionary rule than in states that had the rule before Mapp." Oaks, $37 \mathrm{U}$. Chi. L. Rev. at 708 (cited in note 5).

${ }^{28}$ See, e.g., Bivens, 403 U.S. at 416 (Burger, dissenting); Oaks, 37 U. Chi. L. Rev. at 726-27.

${ }^{30}$ Oaks, 37 U. Chi. L. Rev. at 727-29.

${ }^{31}$ Id. at 730-31. 
suppressed; and (3) no internal police structure exists to ensure that the police are told that their evidence was suppressed or why. ${ }^{32}$

Third, critics claim, the exclusionary rule does not directly punish police when they violate the fourth amendment and therefore creates no incentive for them to correct their illegal patterns of behavior. ${ }^{33}$

Finally, opponents of the exclusionary rule maintain that officers' in-court dishonesty neutralizes the effectiveness of the rule. ${ }^{34}$ Not only are police often able to fabricate convincing "probable cause,"35 but because the exclusion of evidence frequently returns guilty criminals to the street, judges may "wink" at obvious police perjury in order to admit incriminating evidence. ${ }^{36}$ This study addresses each of these criticisms.

\section{Deterrence: An Operational Definition}

The Supreme Court has provided little guidance as to precisely what it means by "deterrence." In Elkins, the Court asserted that the exclusionary rule would deter constitutional violations "by removing the incentive to disregard [fourth amendment guarantees]." 37 But the Court's repeated calls for proof of the rule's deterrent effect demonstrate that the justices want some evidence-beyond the notion that removal of one incentive is likely to reduce the frequency of previously rewarded behavior-that the rule causes police to adhere to the commands of the fourth amendment.

While this comment does not provide a rigorous behavioral definition of "deterrence," it does note two broad requirements likely to be necessary in any system designed to deter illegal police searches: education and punishment. ${ }^{38}$ In terms of background, it

${ }^{32}$ Bivens, 403 U.S. at 416-17; Oaks, 37 U. Chi. L. Rev. at 730-32 (cited in note 5); Spiotto, 2 J. Legal Stud. at 270 (cited in note 5). See also Lafave and Remington, 63 Mich. L. Rev. at 1005 (cited in note 16).

ss Bivens, 403 U.S. at 416 (Burger, dissenting); Steven R. Schlesinger, Exclusionary Injustice: The Problem of Illegally Obtained Evidence 57 (1977); Steven R. Schlesinger, The United States Supreme Court: Facts, Evidence and Law 29 (1983).

34 Oaks, 37 U. Chi. L. Rev. at 739-41; Spiotto, 2 J. Legal Stud. at 275-76; Schlesinger, Exclusionary Injustice at 57-58.

${ }^{35}$ Oaks, 37 U. Chi. L. Rev, at 730-32.

${ }^{36}$ Donald L. Horowitz, The Courts and Social Policy 252 (1977).

37364 U.S. at 217.

38 This rudimentary notion of deterrence is based on interaction with the Narcotics Section officers, the existing empirical research on the deterrent effect of the exclusionary rule, and the scholarly writing on deterrence in the context of criminal justice. See Johannes 
is useful to note that two types of illegal police searches occur: inadvertently illegal searches, in which the officer does not know she is violating the fourth amendment, and knowingly illegal searches, in which the officer knows or suspects that the search is illegal but nevertheless goes ahead with it. In order to deter inadvertently improper searches, officers must be educated in the requirements of the fourth amendment. Yet because it appears that education is not completely effective (officers continue to make knowingly illegal searches), the deterrent system must also punish the officer when she makes an illegal search. In addition, to the extent that there are inherent systemic barriers to the particular deterrent regime (such as those suggested by the critics of the exclusionary rule), the deterrent system must induce effective institutional or bureaucratic responses to counteract those impediments.

\section{Methodology and Institutional Findings}

This study aimed to learn, directly from Chicago narcotics officers, how the exclusionary rule has influenced their behavior while conducting searches and seizing evidence. ${ }^{38}$ The findings are based on structured interviews with twenty-six Chicago narcotics officers. The interviews were centered on a questionnaire that included both narrowly focused and open-ended questions. ${ }^{40}$

\section{A. The Sample}

The sample was limited to the Narcotics Section because motions to suppress are made in narcotics cases far more frequently

Andenaes, The General Preventive Effects of Punishment, 114 U. Pa. L. Rev. 949 (1966), and Franklin E. Zimring and Gordon J. Hawkins, Deterrence: The Legal Threat in Crime Control (1973).

${ }^{3}$ Some previous quantitative research has been beset with problems because it was tied to particular procedural events such as motions to suppress, see, e.g., Spiotto, 2 J. Legal Stud. 243 (cited in note 5), or the relative usage of search warrants, see Cannon, $62 \mathrm{Ky}$. L. J. at 707-16 (cited in note 5). These events are at best crude measures of underlying police activity. And it is difficult if not impossible to appraise the exent to which these procedural events represent real changes in police attitudes and behavior and the extent to which they represent other factors, such as changes in crime rates. See, e.g., Critique, $69 \mathrm{Nw}$. U. L. Rev. at 740 (cited in note 20 ).

40 The questionnaire focused on the deterrent effect of the exclusionary rule on police behavior. After revisions in response to a field test on two detectives from the Narcotics Section, the questionnaire consisted of 148 questions and took an average of $1-1 / 2$ to 2 hours to administer. Unfortunately, due to time constraints and the demands of the officers' schedules, some of the officers did not answer all of the questions, but generally at least nineteen detectives answered each question. Responses to all 148 questions are not discussed in this comment, but will be the subject of future articles. The interviews took place between March 26, 1986, and June 10, 1986. 
and successfully than in any other area of police work ${ }^{41}$ and because the percentage of narcotics cases lost is more significant than that for other crimes. ${ }^{42}$ The sample was composed of officers from each of the two equal-sized branches of the Narcotics Section: Special Enforcement Narcotics (SEN) and General Enforcement Narcotics (GEN). ${ }^{43}$ Half of the officers in each branch are detectives and half police officers. The sample included half detectives from SEN and GEN, and half police officers from SEN and GEN in order to mimic the composition of both branches. ${ }^{44}$

In an effort to minimize the problem of respondent self-interest, ${ }^{45}$ the survey employed two types of questions. First, a significant part of the questionnaire centered on narrowly focused, descriptive, and opinion-oriented questions concerning discrete aspects of police experience-such as the officers' training in the law of search and seizure, their experiences in court, their reactions and the reactions of their superiors when evidence is suppressed, and the types of situations in which evidence has been lost. These focused questions were designed not to intimidate or inhibit the officers so that their responses would not be unduly defensive or self-interested.

The second type of question involved broader, more sensitive issues. Questions in this category included the following: How much harm does the exclusionary rule do to police work? Should the exclusionary rule be scrapped? How often does the exclusionary rule keep officers from making searches that they should be able to make? How frequently do officers lie in court? These ques-

11 See Joseph R. Tybor and Mark Eissman, Illegal Evidence Destroys Few Cases, Chi. Trib. 1, col. 5 (Jan. 5, 1986) ("Tribune Study"); Oaks, 37 U. Chi. L. Rev. at 685; Spiotto, 2 J. Legal Stud. at 247. This area feels the effects of the exclusionary rule so powerfully because narcotics offenses are often based on possession, and thus when the evidence is lost, nothing remains of the case against the defendant.

12 See Tribune Study at 13 (cited in note 41); Oaks, 37 U. Chi. L. Rev., at 685 (cited in note 5); Spiotto, 2 J. Legal Stud. at 247 (cited in note 5).

13 "Special" is involved in the larger, more complex and unusual cases-particularly the interdiction of large drug shipments from other jurisdictions in the United States and overseas. "General" concentrates its efforts on the investigation of more typical, local drugdealing operations.

14 The sample was comprised of twenty-six individuals. The average officer had 14.9 years of police experience and had spent 3.1 years in the Narcotics Section. All of the officers had spent time in the Patrol Division. Many of the officers had previous assignments in the robbery, homicide, and tactical units and in the Special Operations Group (SOG) or its forerunner, the "Task Force."

's See Janis, 428 U.S. at $452-53$ (suggesting that "response studies" could not be used to study the deterrent effect of the exclusionary rule because they were "hampered by the presence of respondents' interests"). 
tions, it was thought, were far more likely to elicit self-interested responses. In fact, however, they frequently elicited "admissions against interest" rather than "self-serving declarations." 4

In addition, because the narcotics section employs "teambased search"47 investigations, the search experiences of each officer on a team were likely to be similar, and intra-team response comparisons served as a check on the accuracy and honesty of the officers' responses. While a few discrepancies were uncovered, the officers' responses were generally consistent. ${ }^{48}$

\section{B. The Institutional Response to the Exclusionary Rule}

Before presenting the results of the detailed survey, it is important to note the criminal justice system's general response to the exclusionary rule. In the Narcotics Section, several institutional responses challenge the validity of many conventional criticisms-in particular, the claim that because the criminal justice system is not a "monolithic government enterprise," suppressions may penalize prosecutors but have no influence on police misconduct. ${ }^{49}$ Indeed, it is ironic that during the time that Oaks wrote his article and Chief Justice Burger his Bivens dissent-both arguing that the rule did not influence police behavior because prosecutors could not control police procedures-the Chicago police and the Illinois State's Attorney's office were forging a much closer working relationship, resulting in several significant procedural reforms. ${ }^{50}$

16 Examples of the "admissions against interest" included officers' reports that when they began police work, beatings and illegal interrogation were reasonably common, that they each had been sued several times, that judges were frequently right to disbelieve them in court, and that judges treated them disrespectfully in court when the judges did not believe the police officers' stories.

47 Though the investigation preceding a search may be conducted by an individual officer or a pair of officers on the basis of information from informants, most searches are done by "teams" of six officers under the direction of a field sergeant or lieutenant. The Narcotics Section has twelve field sergeants, each with his own team of officers. This study is based on interviews with members of ten of the twelve teams-five from SEN and five from GEN.

48 Analysis of the responses shows that two and possibly three of the responding officers lied, or suffered a lapse of memory, in responding to the questionnaire. Ninety-five percent of all searches, and almost all of the searches in significant cases, are done in teams. Officers $12,16,17$, and 18 were all members of the same team and thus should have had basically identical search experiences. Officer 17 reported one case lost and described it. Officer 18 reported two cases in which evidence was suppressed, but described only one. Officers 12 and 16 said that they had had no evidence suppressed in the last year. Other than this, there were no noted inconsistencies in the responses to the survey questions.

49 Bivens, 403 U.S. at 416-17 (Burger, dissenting). See also Oaks, 37 U. Chi. L. Rev. at 710, 726-27 (cited in note 5).

so These reforms probably occurred in the 1960 s and 1970 s rather than in the 1920 s 
One of the most important was warrant screening: lawyers from the state's attorney's office began to review all police warrants for reliability, to ensure that they were based on probable cause. ${ }^{51}$ In addition, the state's attorney's office began to provide special training sessions in particular problem areas of fourth and fifth amendment law. ${ }^{\mathbf{~} 2}$ Finally, assistant state's attorneys offered to provide advice concerning ongoing investigations. ${ }^{53}$

Still more significant institutional reforms occurred within the police department itself. First, the police department instituted an officer rating system that made the loss of evidence a personal liability to officers by ensuring that suppressions negatively affected an officer's ability to retain her assignments and, to a lesser extent,

(when Illinois adopted the exclusionary rule) for a couple of reasons. First, large absolute numbers of cases were not lost to the exclusionary rule until that time. The 1960 s witnessed an enormous increase in the level of crime, particularly drug-related crime. Second, it was only in the 1960s that the United States Supreme Court began issuing rulings aimed specifically at restricting local police practices. Interview with Edward L. Buckney, Director of the Chicago Police Training Academy, March 24, 1987; interview with Commander Ryle, June 6, 1986.

st This policy is formalized in Chicago Police Department Special Order 84-22 (Dec. 11,1984 ) (supplementing and rescinding prior order 80-25), which states in relevant part: "A [police officer] seeking to obtain a Search Warrant will: 1. Submit the Complaint for Search Warrant and the Search Warrant to an assistant state's attorney for review and approval. 2. Ensure that the assistant state's attorney who examines the complaint enters his signature and a warrant number onto the original copies of both the Search Warrant and the Complaint for Search Warrant." According to Assistant State's Attorney Larry Wherrie, this policy has been in effect for at least ten ye :rs. Interview, March 25, 1987. Commander Ryle notes that at least since 1967 informal policy has required state's attorneys to read police warrants. Interview, Dec. 22, 1986. It is unclear, however, when the informal policy became a formal one.

According to Commander Ryle, warrants are still drafted to comply with the two-part test of Aguilar-Spinelli, see Aguilar v. Texas, 378 U.S. 108 (1964), and Spinelli v. United States, 393 U.S. 410 (1969), because the more lenient "totality of the circumstances" test of Illinois v. Gates, 462 U.S. 213 (1983), is too uncertain. Although Ryle makes clear that Gates has not affected the drafting of warrants, he says he does not know how the decision has affected the state's attorney's role in the warrant review process. Interview, Dec. 22, 1986. Ryle's appraisal was echoed by Major R. Coleman, a law instructor at the Chicago Police Training Academy. Coleman said the training academy still emphasizes the Aguilar-Spinelli test because it is easy to understand and does not unduly limit police officers. Coleman further stated, "We cannot find judges in Cook County who are willing to accept the Gates anonymous informant-type warrant. They want more probable cause than that." Coleman believes that the significance of Gates is largely limited to its "own strange facts." Interview, March 24, 1987.

${ }^{32}$ Assistant State's Attorney Larry Wherrie explained that these training sessions occur generally at the request of the police department and are usually related to problem areas identified by the police or the state's attorney's office. He estimated these sessions occur two to three times a year. Wherrie stated that these training sessions serve two purposes: initially to educate young police officers in the law of search and seizure and to inform officers of changes in the law. Interview, March 25, 1987.

ss Wherrie Interview, March 25, 1987; Ryle Interview, Dec. 22, 1986. 
to obtain promotions. ${ }^{54}$

Also, beginning in the early 1960 s, the Chicago Police Training Academy substantially increased the time and effort devoted to training in search procedures for police recruits, a pattern of improvement that continues to this day. ${ }^{55}$ Further, the Training Academy introduced "in-service training" designed to deal with particular search and seizure problems that officers in the various units faced on the job. ${ }^{8 B}$ Two related internal police review procedures were instituted to reinforce the officers' understanding of search and seizure law. First, officers were required to file a Court Disposition and Attendance Form whenever evidence is suppressed, to explain why the evidence was suppressed. ${ }^{57}$ The second reform was internal review sessions, ${ }^{58}$ in which the officer was re-

34 An officer's efficiency rating is based largely on the number of arrests, the percentage of these arrests that lead to convictions, and a catch-all general efficiency component. In appraising an officer's general performance, the sergeant assigns the officer an efficiency number. An unusual number of suppressions (more than two in a year) would seriously affect that number. Ryle Interview, Dec. 22, 1986.

${ }^{6 B}$ Director Edward Buckney, in reviewing police training materials, noted that when he was a recruit in 1954, the training materials did not include any significant discussion of the law of search and seizure. By the early 1960s, when Buckney joined the staff of the Training Academy, the instructors-often visiting lawyers-had begun to "lecture case law" to the officers. Buckney cited the new Illinois Criminal Code of 1963 as a major factor in improved police understanding of the law. "Before the code of criminal procedure," he said, "all we had was the common law, and it was difficult to teach and reinforce the lessons of the common law. The code of criminal procedure put it all down in black and white where it was easily available to officers." Interview, March 24, 1987.

In the early 1980 s, the curriculum underwent further change. Training time was increased from 8.9 hours to approximately 14 hours and was divided into three parts: (1) discussion of the present state of the law; (2) discussion of departmental policy; and (3) "hands-on" experience. See Arrest Search and Seizure (14 Hour Block), Police Training Syllabus. The police point out that in the last several years, recruits for the first time have begun to receive extensive training in writing search warrants. In the past, this training had been reserved for officers who were in the process of becoming detectives. See Search Warrant Training Materials. Interviews with Director Edward L. Buckney, Sergeant Robert Walker, and Officer Major R. Coleman, March 24, 1987.

ss According to Buckney, in-service training was begun in the early to mid-1960s by 0 . W. Wilson, then Superintendent of the Chicago Police Department. Its purpose, broadly conceived, was to bring officers up to date on changes in the law and new police procedures and to maintain officers' existing skills. Several of the department's recent special orders demonstrate the department's adherence to these goals. See, e.g., Chicago Police Department Special Order 84-11, In-Service Tactical Operations Program (April 27, 1984) (initiating training for all Chicago police tactical officers in "tactical planning and legal execution of search warrants"); Chicago Police Department Special Order 86-4, Deadly Force Training Program (April 7,1986 ) (establishing a training program designed specifically to respond to the Supreme Court's holding in Tennessee v. Garner, 471 U.S. 1 (1985), limiting the use of deadly force to stop fleeing felons). Buckney, Walker, and Coleman Interviews, March 24, 1987.

${ }^{87}$ Interview with Sergeant John Killacky, April 6, 1986.

${ }^{8 s}$ Though these review sessions are not directed by any police special order, according 
quired to recount to his superiors the reasons why evidence was lost. These sessions reinforced the lessons of the courtroom and also forced the officer to confront superiors, who generally expressed their disapproval of the behavior leading to suppression. The Court Disposition and Attendance Form and the review sessions also provided valuable information to police administrative and supervisory personnel concerning the types of searches in which evidence was lost.

Another significant reform was a dramatic, centrally directed increase in warrant use. According to Chief Rudy Nimocks, Commander John Ryle, and many of the officers interviewed, in the early 1960 s police seldom used warrants. ${ }^{59}$ In the early 70 s, however, the Narcotics Section adopted a policy that every search, if at all practicable, would occur pursuant to a warrant. ${ }^{60}$ Today, virtually all preplanned searches that are not "buy busts" or airportrelated searches occur with warrants. ${ }^{61}$ Further, the Narcotics Section instituted the process of "informant registration." The police photograph and number their informants and carefully monitor the reliability of all information supplied by each informant. The file established on each informant is available to judges at in camera hearings, to the state's attorney's office, and to a select group of police officials. ${ }^{62}$ As a result of these institutional reforms, evidence from searches based on warrants in the Narcotics Section very rarely is suppressed. ${ }^{63}$

to police officials and the officers interviewed in this study, they occur every time that evidence is suppressed in the Narcotics Section.

so Interview with Chief Rudy Nimocks, then Superintendent of the Organized Crime Division of the Chicago Police Department, Feb. 1986.

$\because$ Id.

61 Killacky Interview, April 11, 1986.

62 This policy is formalized in Organized Crime Division Special Order 86-04 (Dec. 29, 1986, supplementing and rescinding prior order 83-01). The order states in relevant part: "The Narcotics Section of the Organized Crime Division will ensure that all [confidential informants (C.I.'s) are registered. A C.I. must be registered in order to be used as an anonymous source of information; to be the subject of a letter of consideration to a prosecutorial agency; and to receive money in reimbursement of expenses or as an incentive." The order also establishes procedures to record the informant's reliability.

63 According to figures released by the Narcotics Section, evidence was lost in 1.6 percent of all Narcotics Section cases in 1984. This figure includes evidence gathered from searches conducted both with and without search warrants, but does not include "on view" searches. In 1985, 1.9 percent of all cases were lost to the exclusionary rule. See Memoranda from Y. O. Christine Kolman to Commander John Ryle, Jan. 1, 1986 and July 24, 1986. Sergeant Killacky suggests that most of these cases involved warrantless searches. Interview, April 4, 1986.

Suppressions also have decreased because the police have curtailed abusive interrogation practices. Ryle Interview, Dec. 22, 1986. Some of the officers commented that until the 
Finally, in the 1960s the police began to keep statistics on the number of cases lost to illegal searches. For the first time, administrative and supervisory personnel had an overview of the frequency of illegal police activity to which they could respond. ${ }^{64}$

\section{The Exclusionary Rule as a Deterrent to Individual Police Officers' Misconduct}

\section{A. Police Accounts of Suppression Experiences}

Within the sample, nine distinct cases of suppression were reported. ${ }^{65}$ Only one of these cases involved a defective warrant. The warrant had an incorrect address that an officer had typed on the warrant form without checking to see whether the address provided by an informant was accurate.

Three of the cases, as described by the officers, involved searches that seemed clearly improper. In one case, a young, relatively inexperienced officer ${ }^{66}$ made an improper Terry ${ }^{67}$ "stop and frisk" that turned up a soft package of marijuana. ${ }^{68}$ In another case, an officer and his partner entered and searched a suspect's house when an informant with $\$ 850.00$ of police "buy" money unexpectedly entered the house. The officers assumed that their action was justified by exigent circumstances. ${ }^{69} \mathrm{~A}$ third case involved a search improper in scope. The police had a warrant confined to the "rear room" of a barber shop. In an adjacent room they saw a

early 1970 s, officers beat suspects during interrogation with phone books or with rubber hoses (because, just as the old detective reported, they did not leave any marks). Further, officers referred to a technique called "the hook." Suspects were handcuffed in a holding room and left there for hours or even days until they confessed. Indeed, one officer said that in "the old days" suspects sometimes were hung out the ninth floor window of 1122 South State Street, the central police headquarters in Chicago. Other officers spoke of a gambit called "musical chairs," in which a suspect was moved from precinct to precinct so that he could not be found by his lawyer.

64 Both the Narcotics Section and the state's attorney's office keep statistics on the number of cases lost through the operation of the exclusionary rule. See Memorandum from Kolman to Ryle (cited in note 63). The state's attorney's office, which keeps more detailed statistics than the police, refused to release its figures for this study. Wherrie Interview, March 25, 1987.

65 For the full text of the officers' responses, see Appendix, Police Accounts of Suppression of Evidence.

${ }^{68}$ Officer 14 was one of the youngest and least experienced officers in the sample pool, with only $3-1 / 2$ years as a police officer. (The average experience level of the officers interviewed was fifteen years.) In another part of the interview, he noted that a judge had "reamed all over him" in connection with a recent suppression.

${ }^{67}$ Terry v. Ohio, 392 U.S. 1 (1968).

6s See Appendix, Case Four.

${ }^{69}$ See Appendix, Case Eight. 
briefcase. They entered this room, opened the case, and found heroin inside. ${ }^{70}$

One case of suppression may have turned more upon a factual assessment made by the presiding judge than upon a clear fourth amendment violation by the police. In this case, police officers followed a Chicago pharmacist who had driven over 400 miles to a small Kentucky town to purchase large quantities of codeine-based syrup. The police had information that the pharmacist was regularly buying large quantities of codeine syrup and in turn diverting large quantities of it to clients. Shortly after he had arrived at his home with the syrup, the pharmacist suddenly drove away in the van with the syrup. Perhaps realizing he was under surveillance, he chose a zig-zag course in a direction away from his pharmacy. The police, relying on the exigent circumstances exception to the warrant requirement, stopped him and seized the syrup. In suppressing the evidence, the judge apparently did not consider the facts sufficiently suspicious to warrant a search and seizure. ${ }^{71}$

In the four other instances of suppression, the judge apparently did not believe the police officer's stories, suggesting that cases in which judges distrust police testimony may constitute a significant percentage of the cases in which evidence is suppressed in Chicago narcotics court. ${ }^{22}$ In one case, the judge simply did not believe that the police officer could have seen the suspect transfer a package of drugs to another individual from "a block or two away." "I In the second case, the police, holding a search warrant for the suspect's hotel room, claimed that they observed the suspect leave his room, pick up a bag near a tree, and drive away. The police stopped the car and according to their account observed the bag (which they believed to contain cocaine) in plain view through the window. The judge apparently did not believe the story and suppressed the evidence. ${ }^{74}$ In the third case, one member of the police team testified that while searching an apartment pursuant to a proper warrant, he saw a person run out the back door and toss a large plastic bag by the garage. The bag contained narcotics and marijuana. The judge apparently did not believe this story and

${ }^{30}$ See Appendix, Case Five.

"See Appendix, Case Three (two accounts of the same search). Indeed, officer 9 surmised that the evidence was suppressed because judges, as fellow professionals, are unwilling to convict pharmacists of diversion. See id.

${ }^{32}$ This, of course, assumes that the officers were correct to conclude that the judges' disbelief formed the basis of the judges' decisions.

${ }^{73}$ See Apendix, Case One.

"See Appendix, Case Two. 
ruled that the search was improper. ${ }^{75}$ In the fourth case, a pair of officers, observing a house thought to be connected with drug dealing, saw a man and a women leave the house and rapidly drive off. After the car went through a stop sign, the officers pulled it over and, they later claimed, saw the man hand something to the woman. The officers testified that when they reached the car, they saw a plastic bag sticking out of the zipper of the woman's pants. They seized the bag and found heroin in it. The judge did not believe the bag was exposed and suppressed the evidence as the fruit of a search that was too extensive in scope. ${ }^{76}$

In three of the four cases that turned on officer credibility, the police had obtained presumably valid search warrants-albeit for other or narrower searches-in connection with their investigations of the suspects whom they ultimately arrested. Further, in all but one of these cases, other officers involved in the searches supplied corroborating evidence. This small sample tentatively suggests that at least some judges in Chicago narcotics cases are not "winking" at illegal police activity but rather are independently, perhaps even aggressively, evaluating the veracity of police testimony at suppression hearings.

Significantly, if the officers' descriptions of the suppression cases had been believed, they would have provided sufficient probable cause to search (suggesting at least that these officers did understand the law of search and seizure). Indeed, all nine accounts show the officers' clear understanding of the legal basis of the suppression, a fact that comports with the officers' statements that they virtually always understood why evidence was suppressed. ${ }^{77}$ And when the officers began discussing the reasons why evidence had been suppressed, their colloquial, often rambling patterns of response became pointed and clear. The officers spoke the language of the courtroom with considerable fluency, using such terms as "probable cause," "within the scope of the warrant," "exigent circumstances," "in plain view," and "protective search." This seems to suggest that testifying in court before a hostile adversary and an impatient and possibly skeptical judge has salutary effects: the officer must carefully consider whether he had a legally accept-

75 See Appendix, Case Six.

${ }^{76}$ See Appendix, Case Seven.

77 In six of the nine reported suppressions (cases One, Two, Three, Six, Seven, and Eight), assuming the officers' stories were true, the officers lost evidence when they were conducting a surveillance and something unexpected happened before probable cause could be established. In each case, if the investigations could have been completed as planned, the searches apparently would have been proper. 
able basis for his action; and whether this action might be questioned. The preparation for court appears to reinforce lessons so strongly that months and even years later some officers can remember exactly what happened and why evidence was suppressed. ${ }^{78}$

B. The Role of the Chicago Narcotics Courts in Educating the Police in the Requirements of the Fourth Amendment

Critics of the exclusionary rule assert that the police are often unaware of the disposition of motions to suppress, even though they may have testified in court, because of delays in the legal process generally and in the appellate process in particular. Thus, the critics suggest that the exclusionary rule cannot affect police officers' behavior. ${ }^{79}$ Moreover, even if the police know that evidence has been suppressed, critics maintain that the officers often do not understand the reasons for suppression. They cannot understand the judge's ruling; the prosecutor does not explain it to them; and no other official or institution ensures that the police understand..$^{80}$ Not one of these criticisms seems true today in Chicago narcotics court.

1. Police knowledge of cases in which their evidence has been suppressed. Even in the early 1970s, when critics asserted a general lack of police knowledge, an extremely small percentage of convictions obtained by the Narcotics Section were overturned on appeal. ${ }^{81}$ Then as today, the suppression nearly always occurred much earlier, usually at the conclusion of a hearing before the trial court on a motion to suppress. Slow-moving appellate courts seem unlikely to impair Chicago officers' understanding of the exclucionary rule.

When asked whether they always find out when their evidence has been suppressed, seventeen of the twenty officers responding (85 percent) answered "yes." Although three officers responded

78 Some of the officers could repeat with equal ease the stories of evidence that had been suppressed five, ten, and even fifteen years before.

79 See, e.g., Oaks, 37 U. Chi. L. Rev. at 730-32 (cited in note 5); Bivens, 403 U.S. at 417 (Burger, dissenting).

${ }^{\text {so }}$ See, e.g., Oaks, 37 U. Chi. L. Rev. at 730.

81 Spiotto reports that between 1965 and 1971, defendants exercised their right to appeal the denial of a motion to suppress in 179 cases and were successful only 16 times. $2 \mathrm{~J}$. Legal Stud. at 251 (cited in note 5). Given the average total of 8,000-9,000 narcotics cases per year during that period, the effect of appellate reversal on police understanding of the exclusionary rule in Chicago appears insignificant. Ken Waddas reports that current statistics are similar. 
"no," each indicated that he found out approximately 90 percent of the time when his evidence had been suppressed..$^{22}$ When asked how quickly they discovered that evidence had been suppressed in one of their cases, all of the officers responding answered "right away" or "immediately." When asked what was the most likely way for officers to find out that evidence had been suppressed, all of the responding officers said that they were most likely to find out that evidence had been suppressed while in court. ${ }^{83}$

Police supervisory personnel confirmed the officers' judgement that they virtually always find out when their evidence has been suppressed because they are almost always in court when the judge rules on a suppression motion. ${ }^{84}$ In addition, the supervisors described several of the Narcotics Section's procedural reforms that ensure that officers learn of suppressions. As noted earlier, officers are required to file Court Attendance and Disposition Forms explaining the disposition of suppression motions. Officers may also learn of suppression through a "kicker sheet" that reports the disposition of all cases in the Narcotics Section. And at individual

82 One of these officers believed that he learned "90 percent of the time" if his evidence had been suppressed; another officer estimated that he found out " 95 percent of the time"; and the third officer estimated that he found out when his evidence had been suppressed "80-90 percent of the time." He stated, "Sometimes you don't find out if it is up in trial court. Although you can see it on a kicker sheet, that doesn't tell you why. You have to call the state's attorney if you want to find out why. But most of the time you're going to be there even if they don't call you to testify in court."

${ }^{83}$ Question 16 asked: When evidence that you have seized is suppressed, how do you find out?

\section{RESPONSES}

a. In court

b. Response (a) and call state's attorney

c. Responses (a), (b) and hear from superiors

d. Call state's attorney/"kicker sheet"

e. No response

\section{OFFICERS}

$20(80 \%)$

$3(12 \%)$

$1(4, ;)$

$1(4 \%)$

$1(0 \%)$

Question 16(a) asked which of the above ways of finding and about suppression was most likely; all of the officers answered "in court." A "kicker sheet" is a memorandum circulated by a lieutenant showing the final disposition of all court cases in which the officers of the Narcotics Section participated. Elaborating on his response, Officer 18 said, "If I recover evidence on a search warrant, I have to be in court, that's all there is to it. . . . I am in court the first and third Wednesdays of every month. If I am the case officer or affiant on the warrant, I always testify." Two of the officers commented that if a case were appealed, they would typically call the state's attorney. One officer said that in this same situation, the state's attorney would call him and tell him. Two officers said that if a case were reversed on appeal, they would hear from their superiors.

s4 Commander Ryle maintains that officers are "always" in court when the judge rules on a motion to suppress. Interview, Dec. 22, 1986. 
suppression review sessions, a sergeant and often a lieutenant, sometimes accompanied by an assistant state's attorney, go over the suppression of evidence in a case in painstaking detail with the officers responsible. Finally, the prosecutor's office makes an effort to inform the police even of the appellate dispositions of suppression motions; Ken Waddas, the assistant state's attorney formerly assigned to the Narcotics Section, reported that his office routinely called police officers to inform them of appellate rulings.

Officers not only know when their evidence has been suppressed; they also generally understand, while in court, why it has been suppressed.85 When asked how often they had a "good or complete" understanding of the reason for suppression, one-third of the officers responded that they "always" understood why their evidence was suppressed while they were in court. ${ }^{86}$ Thirteen of the twenty-four officers responding reported that they "usually" understood why evidence had been suppressed while they were in court. Three of these officers indicated that they understood why their evidence was suppressed almost all of the time. ${ }^{87}$ Although three officers responded that they only "sometimes" understood why evidence was suppressed while in court, one bad or confusing experience might have had a significant effect on an officer's overall response. ${ }^{88}$ In summary, virtually all of the officers in the Nar-

8s Question 19 asked: When your evidence is suppressed, how often do you have a good or complete understanding of why it was suppressed?

\section{RESPONSE}

a. Always

b. Usually

c. Sometimes

d. Seldom

e. Never

f. No response

\section{OFFICERS}

$$
\begin{aligned}
& 8(33 \%) \\
& 13(54 \%) \\
& 3(13 \%) \\
& 0 \\
& 0 \\
& 2(0 \%)
\end{aligned}
$$

s6 Officer 27, who responded "always" to Question 19, also said, "If I get something thrown out, I have the defense attorney xerox the case law, and if I don't understand it, I ask the assistant state's attorney how to draw parallels from it. I try to figure out since the last time I was there what changed."

${ }^{87}$ Two of the officers who answered "usually" specifically pointed out that while they could not say they always understood why their evidence was suppressed in court, they believed that they understood "almost always." Another of the officers who answered "usually" indicated that he understood the reasons why evidence was thrown out " 90 percent of the time." Two of these officers reported that if they do not understand the judge, they simply ask for clarification and the judge is generally very helpful. Finally, one of the officers who answered "usually" said, "If I don't understand the judge, I'll ask the state's attorney, unless he is real busy."

ss One of these officers explained that recently he had had evidence suppressed for the 
cotics Section knew when evidence was suppressed and understood why.

2. How effective are suppression hearings in teaching officers about the law of search and seizure? One question asked officers how they found out about changes in the law of search and seizure. It provided the following five alternatives: "through written rules given to the police; through lectures or presentations outlining changes in police policy; through the officer's experience having evidence suppressed; through an officer's experience seeing another officer's evidence suppressed; other." Twenty-three of the respondents (95 percent) listed their own experience as one way of learning about changes in the law, and twenty-two (92 percent) thought that seeing another officer's evidence suppressed was edifying. ${ }^{89}$ When asked which of the listed factors was the most significant, twenty of the twenty-two responding officers (90 percent of the officers responding) chose the experience-based forms of learning. Eight officers (36 percent) reported that their own experiences had taught them the most about changes in search and seizure law, while eleven (50 percent) thought their own experience and witnessing other officers' evidence being suppressed were equally significant. ${ }^{90}$

These responses, along with the officers' accompanying comments, indicate that Chicago narcotics officers believe they learn most about changes in the law of search and seizure from in-court

first time in "a couple years." When it happened, "The judge yelled at me. I still don't remember what he was saying. I have trouble understanding when they yell at me. If they explain in a calm way, I understand why."

so Question 44 asked: If the law of search and seizure has become more complicated over the years, how have police found out about it? (You may select more than one alternative.)

\section{RESPONSE}

OFFICERS

a. Written rules/lectures and presentations/officer's own experience/through another officer's experience

b. Written rules/officer's own experience/through another officer's experience

c. Officer's own experience/through another officer's experience

d. Lectures and presentations/officer's own experience/through another officer's experience

e. Written rules

f. Officer's own experience

g. No response

${ }^{\text {so }}$ Question 45 asked: Which of the above factors is most significant? 
experience. The officers' responses to other parts of the survey, particularly those related to training and the lessons learned in court, ${ }^{91}$ confirm that in-court experience is not only the most important way of learning about changes in the law, but also the most effective way of learning about the law of search and seizure in general. Although the officers uniformly believed training was important in understanding the law, they also believed that the lessons of training did not firmly take hold until the officers faced real-life situations in the courtroom.

3. How often do police officers learn something from having evidence suppressed? When asked how frequently they learned something from the suppression of evidence in one of their cases, fourteen of the twenty-three officers responding (61 percent) believed they learned something either "very frequently" or "every time" that evidence was suppressed. ${ }^{92}$ One of the officers, who answered that he learned something "very frequently" from having evidence suppressed, commented: "You get evidence suppressed and you try to do it differently from that point on, and that's all there is to it."

Nine officers (39 percent) believed that they learned something new from suppression only "occasionally" or "rarely." Judging from the officers' accompanying comments, it appears that there are at least two explanations for officers' not learning: (1) the

\section{RESPONSE}

a. Officer's own experience/another officer's experience

b. Officer's own experience

c. Lectures and presentations/another officer's experience

d. Written rules

e. Another officer's experience

f. No response

\section{OFFICERS}

$11(50 \%)$

$8(36 \%)$

$1(5 \%)$

$1(5 \%)$

$1(5 \%)$

$4(0 \%)$

92 See Appendix, Question 22.

92 Question 21 asked: How frequently have you learned something from evidence in one of your cases being suppressed?

\section{RESPONSE}

a. Every time

b. Very frequently

c. Occasionally

d. Rarely

e. Never

f. No response

\section{OFFICERS}

4 (17\%)

$10(43 \%)$

$5(22 \%)$

$4(17 ; a)$

0

$3(0 \%)$ 
law of search and seizure is not unduly complicated and most of it is already known by the officers; ${ }^{93}$ and (2) evidence is continually suppressed in similar circumstances, often related to "on view" or warrantless searches. ${ }^{94}$ Here the officer often realizes the search and seizure may not be upheld as reasonable but would prefer to take the risk in confiscating the evidence rather than allowing the suspect to keep it.

4. What do police officers learn from having evidence suppressed? Officers were asked what specific lessons they had learned from having evidence suppressed. The responses indicate the officers learned lessons in the law of search and seizure and the need for specificity in preparing case reports. ${ }^{95}$

First, officers learned the law of search and seizure. In particular, many of the officers observed that they had learned to be more careful in the context of warrantless searches. Officer 3 noted, "As a young cop, I learned that I'd better have a good reason before I search a car. I'd better have more than just 'apparent drunkenness." " In a similar vein, Officer 8 answered, "Before stopping people in a neighborhood at a late hour, you better have a good reason. Just late hours is never enough. I used to think that saying 'late hours' was enough." Other officers commented that they had learned of the special care necessary in street stops or "on views." Officer 18 noted, "Specifically, I've learned about street stops. We make sure we have probable cause to make a street stop before we do it." Officer 24 echoed this sentiment: "You do a questionable street stop and nothing holds. It gets tossed out. The lesson? You can't be too careful." Officer 4 reported, "I learned that the vast majority of your on view cases are losers." "96

93 Three of the four officers who responded "rarely" volunteered additional comments. One observed: "You always know when the stuff is going to be suppressed if it is. You have no other recourse. . . . It has to be seized or else it's on the street. But you always know when it will be suppressed." A second officer stated, "It is the same thing over and over again. It's almost always an on view or something like that. Basically all it is is common sense." The third officer said, "You know exactly what you are doing ahead of time. The rules are simple. Generally I know when I am in a position in which the evidence will be thrown out, but I say to myself, 'make the pinch.' Why in the fuck should I cut 'em loose? Not me; you cut 'em loose and the substance is still in the game."

or An "on view" is a search based on an officer's direct observation of illegal drugs or of drug-related activity. A "drop" case is an "on view" in which the suspect allegedly drops the controlled substance on the ground after he is seen by the officer. Increasingly over the years, judges have become skeptical of "drop" case stories. The police maintain that as judges have become skeptical, narcotics users have increasingly used this technique to frustrate police action.

${ }^{95}$ For a full text of the officers' responses, see Appendix, Question 22.

${ }^{96}$ Officer 22 estimated that "about 50 percent of 'on views' are losers." Another officer 
Several of the officers noted that they had developed a decided preference for using warrants when they conducted searches. Officer 25 commented in relation to a recent case, "We thought we had exigent circumstances. The next time we will secure the place and get a warrant." ${ }^{\prime 27}$ Officer 28 noted, in the context of a controlled purchase of drugs: "I learned that you shouldn't do a buy bust without a warrant. Now I type up a warrant and then I have a buy as well as the possibility of doing a search warrant. I can get him two-handed." 98 Officer 29 emphasized, "It is always the stronger case doing a search warrant."

Many officers also mentioned learning specific technical lessons in the law of search and seizure. Officer 9 noted, "I learned about 'fruit of the forbidden tree.' By the law, if it is an illegal stop ... all evidence that came in any way from that stop is illegal and can't be used by the patrolman." Officer 20 , previously assigned to homicide, noted that he had learned the following difference between narcotics and homicide searches: "I learned something about when you have immediate information and no time for a warrant. A year ago, I went into somebody's house. In homicide, you could say personal injury was at stake in a situation like this. I learned that this doesn't apply to narcotics." Officer 13 described how he had learned to protect "drop cases" from successful motions to suppress: "When somebody drops a bag, you look at it closely before you search the perp[etrator]."

The lessons described by the officers represent some of the best evidence produced by this study of the educational aspect of the exclusionary rule's deterrent effect on unlawful police behavior. When evidence is suppressed, the officers learn about the law of search and seizure and apply these lessons to bring their search activity into line with the requirements of the fourth amendment.

estimated that 30 percent of "on view" cases were lost because judges did not trust police testimony.

${ }^{27}$ Officer 25 was referring to a case noted earlier (see Appendix, Case Eight), in which an officer had entered a house to conduct a search after $\$ 850$ of police "buy money" had disappeared into the house.

${ }^{98}$ A "buy bust" is an arrest based on a controlled purchase of drugs from a suspect. First, the police officer receives information from a confidential informant. The informant introduces the officer to the suspect to arrange an initial drug purchase by the officer. Because it is generally not possible to buy over 15 grams of heroin or 30 grams of cocaine (possession of such quantities constitutes a Class $\mathrm{X}$ offense in Illinois) without establishing some sort of reliability or credibility, the officer frequently must make two or three "buys" to "class X the offender." Once the officer has made a sufficient purchase from the offender, other officers arrest him directly after the "buy." Many of the officers interviewed felt that this was their most effective method of ensuring conviction. 
In particular, the responses show that the exclusionary rule has caused the officers (1) to be especially careful in the context of warrantless searches and (2) to use warrants when at all possible-lessons the exclusionary rule clearly was intended to impart.

The second lesson from suppression was a practical one. The officers asserted that their time in court was itself a valuable learning experience, particularly in understanding how fourth amendment rules operate in practice. In this light, Officer 18 stated, "Going to court is more concrete than training. It is on-the-job training, and like on-the-job training it is the most useful way of learning." Officer 5 added, "Even though I feel I understand the law and the rules of evidence, the real lessons in this whole thing have to do with experience of the judicial system-to see what things are really like in court. It is easy to read about what probable cause is, but you don't know the reality of probable cause until you get to court. When you are in court, you find out what gets past the judge and what doesn't." Officer 17 had this to say: "You learn that different things are treated differently [in court]. It depends on the judge's perception. One judge might think something is important, another won't. You learn that good lawyers make a lot of difference and can make things seem different than they really are."

Suppression also has taught the officers to be more thorough in their case reports. The case report is a document that an officer must file within eight hours of an arrest, a search, or a seizure, describing the circumstances surrounding the officer's action. To ensure accurate police testimony, the officers reported that it has become a rule in the Chicago narcotics court that an officer cannot testify with respect to anything not listed in his case report. Thoroughness in these reports thus becomes extremely important, particularly in terms of events and observations tending to establish probable cause. Officer 3 noted, "I also learned to carefully list my observations on the police report." Officer 17 agreed, "You learn that you are tied to a specific format, the case report. Everything-where it is, who found it-everything-where on the scene the stuff was, who found it. The format is so exact." Noting the high degree of care necessary in these reports, Officer 18 added, "We want specifics in case reports. You have to be even more specific than in warrants."

5. How often and why do officers have evidence suppressed more than once for the same reason? In response to this question, twelve of the twenty-three officers responding (48 percent) believed that narcotics officers had evidence suppressed for the same 
reason either "rarely" or "never." Twenty-one of the officers (91 percent) believed that narcotics officers had evidence suppressed for the same reason "never," "rarely," or only "occasionally."

The officers' comments indicate that at least some of the time-and in light of the responses to other questions, probably most of the time-the reason that officers seize evidence that is later suppressed is not because they fail to understand the substantive law, but rather because they prefer to take the risk of having the evidence suppressed in order to get it "off the street."100 These responses highlight the difficulty of deterring confiscation searches and other searches in which officers do not care about convictions. Yet there is also reason to believe that such searches are relatively uncommon. When asked how often they conduct searches with little or no thought of obtaining evidence to be used in court, ten of the twenty-three officers responding said "never;" eight said "rarely," two said "somewhere in-between rarely and and never," and one officer answered "reasonably frequently."101

9 Question 23 asked: In general, how often do you think narcotics detectives have evidence suppressed more than once for the same reason?

RESPONSE

a. Rarely

b. Occasionally

c. Very frequently

d. Never

e. Does not know

f. No response

\section{OFFICERS}

$11(48 \%)$

$9(39 \%)$

$1(4,0)$

$1(4 \%)$

$1(4 \%)$

$3(0 \%)$

100 Officer 5, one of the officers who answered "occasionally," added, "If I see about the same circumstances that I did before, I am probably going to do the same thing again. Do I walk away? I don't like it. The only alternative is if I manage to get a little more time, so that I can secure the premises until I get a search warrant signed or something like that." Officer 16, who also answered "occasionally," stated: "It happens occasionally, but you got to get smart. If you do an on view case, you add something in the case report to make it seem like you were proceeding on the basis of reliable information." Officer 10, the officer who answered "very frequently," had this to say: "It's the same circumstances over and over again. . . . You have very little control over a drop case. You arrest him and the judge won't believe it. But the dope goes to the criminal laboratory, and no one's rights are violated."

${ }^{101}$ This evidence undermines the argument, advanced by Oaks and other critics of the exclusionary rule, that police are not concerned with obtaining convictions and so the exclusionary rule cannot deter misconduct. See Oaks, 37 U. Chi. L. Rev. at 720-22 (cited on note $5)$. 
C. The Role of the Chicago Narcotics Courts in Punishing Officers for Illegal Searches

In Bivens v. Six Unknown Federal Narcotics Agents, Chief Justice Burger asserted that the exclusionary rule "does not apply any direct sanction to the individual official whose illegal conduct results in the exclusion of evidence."102 Academic literature on the exclusionary rule likewise has frequently argued that the deterrent effect of loss of evidence to police is negligible; the suppression doctrine does not involve a direct monetary or penal sanction against the offending officer. The officers' responses indicate, however, that in the Narcotics Section punishment related to the suppression of evidence is both real and effective.

1. Punishment and the courtroom experience. Perhaps the most significant form of punishment is the officer's personal disappointment at the loss of a potential conviction. In the Narcotics Section, according to the officers interviewed in this study, such a loss-except when an officer has seized evidence simply to deprive the narcotics suspect of its use-is perceived as a personal sanction.

According to the officers, this sense of disapointment is an outgrowth of the nature of police work itself. The investigation leading to a formal search and prosecution often represents a significant investment of time and emotional energy on the officer's part. Sometimes investigations involve literally months of work, night-time surveillance, and/or surveillance under tedious, physically uncomfortable, and dangerous conditions. The significant amount of time spent on these investigations, together with their danger and uncertainty, create a strong emotional commitment to conviction.

Several officers indicated that suppression hearings themselves were a form of punishment. The experience was particularly unpleasant in the 1960s before officers knew how to prepare for the rigorous questioning by hostile defense attorneys. Uneducated to the fine points of the fourth amendment and given little assistance by overworked state's attorneys, officers often were berated by judges when evidence was suppressed. Before the police and state's attorney's office implemented procedures aimed at teaching officers why evidence is suppressed, the officers' humiliation was compounded by confusion. ${ }^{103}$

${ }^{103}$ This general description was constructed from various conversations and comments 
Even with the greater emphasis on officer preparation ${ }^{104}$ and increased cooperation between the police and the state's attorney's office, some officers feel that at a suppression hearing it is still the police officer, not the criminal defendant, who is on trial. The officer's behavior and judgment are closely scrutinized and a decision to suppress evidence reflects a direct judicial assessment of the officer's conduct.

Officers often associate the outcome of a case with their performance. This explains the deterrent effect of the rule in a "big pinch" situation. It is less clear that the rule deters misconduct in "small pinch" cases in which the office has not developed a commitment to conviction. ${ }^{105}$ Cases of this sort typically involve "street stops," "on views," and "drop cases." According to all available statistical studies ${ }^{108}$ and according to the officers interviewed, the vast majority of suppressions occur in this area. ${ }^{107}$ Yet the officers interviewed in this study also reported that these warrantless stops and searches are becoming much less common. Several officers indicated that they no longer make many street stops. They stated that these stops are not worth the time and trouble of going to court given the likelihood of what they termed "abuse" at the hands of defense attorneys and of judges increasingly skeptical of confiscation searches.

When asked what happens at suppression hearings, 90 percent of the officers responding stated that defense attorneys try to make them look incompetent. Forty percent of the officers reported that the defense attorneys try to make them look dishonest, and 30 per-

with all of the officers, but particularly from conversations with Sergeant John Killacky and an interview with Lieutenant E. S. Karczewski, March 26, 1986.

tos Karczewski Interview, March 26, 1986.

${ }^{10 s}$ The "big pinch" is a term used by Skolnick to denote a search that is important to the officer and that she hopes will lead to a conviction; the "small pinch" is Skolnick's term for a search in which the officer seeks only to arrest the individual and is not concerned with a conviction. See Skolnick, Justice Without Trial (cited in note 16).

${ }^{106}$ See Tribune Study at 13, col. 1 (cited in note 41), (98 percent of the cases in which evidence is suppressed involve defendants who, if convicted, would be sentenced to probation or to a jail term of less than six months). Spiotto found that over half of the successful motions to suppress in narcotics court in 1971 involved misdemeanor marijuana charges. An additional 15 percent involved the felony possession of marijuana, and at least a portion of these probably would be misdemeanors now, after the decriminalization of possession of certain quantities of marijuana. See Spiotto, 2 J. Legal Stud. at 263 (cited in note 5).

${ }^{107}$ In response to Question 15- "Is evidence suppressed with unusual frequency in any particular type of case that you deal with as a narcotics officer?"-nineteen of twentytwo officers reported that most suppressions occurred in relation to "on views, "drops," and "traffic stops." 
cent stated that judges treat them disrespectfully. ${ }^{108}$ The officers are probably especially reluctant to bear these "process-related" costs when the case is small.

Again the comments that the officers volunteered provide valuable insights. All of these comments described suppression hearings as negative experiences. Several of the officers commented that at suppression hearings, the main tactic of the defense attorneys was to try to discredit the officers and that the attorneys would do anything to accomplish that objective. Not surprisingly, the officers appeared hostile to defense attorneys as a group. ${ }^{109}$ Officer 8 concluded derisively that "defense attorneys are showboats sometimes," indicating that the defense attorneys used flamboyant and dramatic tactics to discredit the officers at a suppression hearing. Officer 10 also said that "the defense attorney tries to make me look incompetent . . . they try to beat you." Commenting on the general strategy of defense attorneys, Officer 27 remarked, "Generally they try to rattle you. They ask you questions like, 'How long have you had your job?'-general background information stuff. The point of all this is to show that you're not careful, that you don't care about conducting a careful search." Finally, Officer 28 added that "the defense attorney will try to make you look incompetent, but they can't do it."

In response to an open-ended question-"When evidence in a case that you have been working on is suppressed, what are your usual reactions?"-roughly half of the officers reported feeling dis-

${ }^{108}$ Question 63 asked: What sort of things happen to you at a suppression hearing?

\section{RESPONSE}

a. the defense attorney tries to make you look incompetent

b. the defense attorney tries to make you look dishonest

c. the judge treats you disrespectfully

d. responses (a) and (b)

e. responses (a), (b), and (c)

f. responses (a) and (c)

g. responses (b) and (c)

h. None of the above

i. All of the above

j. No response

\section{OFFICERS}

$8(40 \%)$

$1(5 \%)$

$0(0 \%)$

$3(15 \%)$

$2(10 \%)$

$2(10 \%)$

$1(5 \%)$

$1(5 \%)$

$2(10 \%)$

$6(0 \%)$

${ }^{109}$ Question 80 asked the officers, "Which of the following terms accurately characterize most of the defense attorneys that you have encountered?" It then provided twenty-two optional responses. The officers' most frequent responses were "concerned only with their fee" (14 officers), "often 'con' their clients" (11 officers), "unconcerned with justice" (10 officers), "disrespectful of the police" ( 6 officers), and "dumb" (4 officers). 
appointment and/or frustration.110 Officer 18's comments typify this sentiment: "I am disappointed. I don't like to lose a case on a technicality. It bothers you. I don't like to see a drug dealer go on a technicality." Officer 29 responded, "I get pissed off." Officer 27 responded in somewhat more emphatic terms, "I kick myself in the ass. I demand something for an explanation."

Several of the officers commented that they directly correlate the degree of their disappointment and/or frustration to the amount of their effort or to the general importance of the case. Officer 4 noted, "It depends on the case. If it is a large quantity, then I am upset. If it is two or three sticks of marijuana, I don't get crazy. If it is a large quantity, I question why." Officer 22 echoed this sentiment, "It depends on the case and how hard you worked on it. You take extra precautions and make sure it is not thrown out if you care about the case." Explaining his reaction when evidence was suppressed, Officer 5 noted that his sense of frustration depended on whether he considered his action correct: "If I feel my decision was right, I am frustrated."

Finally, one officer (Officer 29) suggested that his sense of anger was related to the fact that some evidence was being suppressed dishonestly by judges who take bribes. He stated: "[Defendants] pay their lawyers a lot of money. The judge is not 100 percent. I've been in trial, somebody says, 'Delivery for ' In a delivery trial, they would normally find the guy guilty. Then there is a 'motion to fix.' . . . This happens in bench trials, otherwise they're not able. It happens 5 percent of the time or more."

The other half of the responses in this section indicate an effort on the part of the officers to "professionalize" the experience of having evidence suppressed and to detach themselves from feelings of frustration and anger. ${ }^{111}$ Of these officers, the majority attempt to learn from the experience of suppression. ${ }^{112}$ Officer 10's remarks were representative of this category: "I am analytical. I ask, 'What can I learn from it? Should it really have been suppressed? What do I do about it in the future?' It is a learning experience. It does me no good to beat my head against the wall."

Only three officers viewed the loss of evidence either as not

110 See Appendix, Question 20, responses of Officers 4, 5, 15, 18, 22, 27, and 29.

"11 See Appendix, Question 20, responses of Officers 7, 8, 10, 17, 24, 25, 27, and 28. Note that there is some overlap between these two categories of responses.

11 See Appendix, Question 20, responses of Officers 8, 10,17, 24, 25, and 27. 
particularly upsetting or as an inevitable part of the job. ${ }^{113}$ Officer 17 noted that he generally knew when evidence was going to be suppressed beforehand, indicating both his knowledge of the law of search and seizure and the reason for his lack of disappointment. Officers 17 and 28 commented that their disappointment was diminished by the realization that individuals likely to continue as drug dealers or "repeat players" would eventually be caught.

2. Institutional "punishment" of police officers. In 1970, Dallin Oaks wrote:

An officer may of course experience disappointment at seeing evidence suppressed and an offender go free, and that experience may affect his future behavior. If the officer also had to suffer departmental discipline and forfeit promotion, prestige, or other advantages because of the application of the exclusionary rule to his cases, then this could give the exclusionary rule an important special deterrent effect. But diligent inquiry has failed to reveal a single law enforcement agency where individual sanctions are tied to an application of the exclusionary rule. The rule is apparently expected to achieve its purpose without them. ${ }^{114}$

In the Narcotics Section, strong institutional "punishment" mechanisms do exist to deter violations of the fourth amendment. First, as a general rule in the Narcotics Section, two suppressions in other than minor cases cause an officer's transfer or demotion. This policy is reflected in the officers' responses to the question, "Could a pattern of repeatedly having evidence suppressed cause an officer to be transferred out of narcotics?" Twenty of the twenty-two officers said "yes." The other two officers responded that "they did not know."

Indeed, supervisory personnel apparently express concern whenever evidence is suppressed. ${ }^{115}$ When asked to characterize their superiors' reaction to supressions, sixteen of eighteen responding officers (89 percent) believed that their superiors were "concerned" when evidence was suppressed. Several officers specifically noted that when evidence was suppressed the incident was

113 See Appendix, Question 20, responses of Officers 7, 19, and 28. Officer 14's response that "it's just part of the job" was not included in this category because in another part of the interview he complained about being "reamed" (or berated) by a judge in response to another question.

114 Oaks, 37 U. Chi. L. Rev. at 710 (cited in note 5).

115 For a complete text of the officers' responses, see Appendix, Question 25. 
always reviewed by their superiors. ${ }^{116}$ In these review sessions, the superior tried to find out why the evidence was suppressed ${ }^{117}$ and to ensure the officers did not make the same mistake twice. ${ }^{118}$ Many officers noted that even a small number of suppressions would cause an officer to be transferred from the unit. ${ }^{119}$

Yet, while superiors review all suppressions, they treat cases not aimed at obtaining convictions with less seriousness. The officers' responses indicate that cases geared toward obtaining convictions, particularly cases involving larger quantities of drugs, are more likely to result in an extensive review session and in disapproval and/or discipline after suppression. ${ }^{120}$

Minor cases do add to the number of suppressions, however, and this number may affect the officers' prospects for promotion. Police officials explained that the department lists the number of suppressions an officer has had as a component of her efficiency rating. Under normal circumstances, they maintain, this factor would have an important effect on an officer's ability to obtain a promotion. Since 1983 (when Harold Washington was elected Mayor of Chicago), a vigorous affirmative action policy has made an officer's overall efficiency rating less important. ${ }^{\mathbf{1 2 1}}$ Nevertheless,

${ }^{116}$ Officer 5 noted, "If they [the officer's superiors] saw a problem, they spend time harping on it a lot more. Nobody likes to lose any cases." Officer 10 pointed out, "Their reaction? They look at the facts involved in the case. If they feel something is wrong, they would advise you."

117 Officer 27 described the experience of a review session as follows: "After something is suppressed you go in and you explain it, then you break it down one more time. You go over it and over it."

${ }^{118}$ Officer 17 concluded, "They are pretty helpful. But don't let it happen again. . . They want you to do something constructive with the experience-to learn something from it." Officer 28 stated, "They make sure you don't make the same mistake twice. They keep a record of the cases that we win and lose."

119 Officer 25 said, "I'll venture a guess that if next year you had high production rate and a low conviction rate, they would whistle you out of here. You will go someplace else."

${ }^{120}$ Specifically, Officer 8 noted, "In connection with a big bust, they become very angry and they reprimand you." Officer 17 commented, "You fuck up on a big case and you hear about it." Officer 18 noted, "Yes, they are concerned about all cases, but they are more concerned about big ones." Officer 24 stated, "It is different with big cases. These cases are all important. They go over it more carefully." Officer 25 revealed, "They are more concerned [in a big case]. In a multi-ounce case, you spend a lot of money, there is a lot of time lost in the case. If it is something you did wrong, you are set down and talked to. They will whistle you out of here the first time, maybe. Two big ones and you're out." For a full text of the officers' responses, see Appendix, Question 26.

${ }^{121}$ Sergeant Killacky reports that prior to 1983, the officers' efficiency rating represented 33 percent of the promotion decision. Now, he claims that it represents 3 percent. Interview, April 11, 1986. However, Commander Ryle reports that although he has no "exact" statistics, he does not believe that this efficiency component ever represented 33 percent of the promotion decision. But he does believe that it was once a great deal more significant than it is now. Ryle Interview, March 23, 1987. 
of six officers asked whether the number of suppressions could affect their ability to obtain a promotion, four of them believed it could be a factor. ${ }^{122}$

Although the officers were reluctant to volunteer information about disciplinary actions related to abusive searches, several officers indicated that harsh penalties could follow bad faith behavior. Officer 10 noted that an individual had been "separated from the department" after search behavior the officer characterized as "highly illegal stuff." Officer 14 responded, "Oh yes, I do know of someone [who was disciplined for a bad faith search]. I won't talk about it. You violate someone's rights and you could go to jail around here. I know that." Officer 28 spoke of an officer who was reprimanded after he had photocopied a valid warrant and used the copy in an unauthorized second search.

Finally, officers clearly believe that a continued pattern of suppression of evidence could affect their reputations both with their superiors and with their peers. The most common responses indicate that an officer's pattern of suppression would engender a reputation for laziness, incompetence, or dishonesty. ${ }^{123}$ Specifically, Officer 5 noted, "It would ultimately injure your reputation as a professional. It would indicate a lack of proper training or work ethic." In somewhat stronger terms, Officer 11 stated, "It would indicate that the officer is an idiot and an incompetent. No one would want him around." Officer 14 said, "It means that the officer hasn't learned a thing and that he has poor work habits." Officer 22 replied, "The officer's peers would think he was stupid."

Of the possibility that a pattern of suppression might make an officer appear dishonest, Officer 15 stated, "The officer would be under suspicion. It might be thought that he is collaborating with the defense." Officer 21 echoed this response: "They would think the officer was crooked." Officer 24 concluded, "People would not want to work with the officer. All of them would know something is wrong."

The officers' responses indicated that repeated suppressions would affect their relationship with their sergeant, ${ }^{124}$ causing the sergeant to think that they were incompetent or dishonest. Officer 9 noted, "He would not trust the guy involved in the case." Officer 10 pointed out: "It is obvious that the officer isn't learning from past experiences and obviously he's not capable of making a good

${ }^{122}$ For a full text of the officers' responses, see Appendix, Question 28.

${ }^{123}$ For a full text of the officers' responses, see Appendix, Question 32.

124 For a full text of the officers' responses, see Appendix, Question 29. 
case." Officer 25 stated, "Everything they do, he'll question them on. The guy's working for you. He might think the guy is crooked. It depends on the sergeant's attitude and the type of case lost. There is not always a presumption of being crooked." While the officers thought that the sergeant would first try to find out why there was a pattern of suppression, they believed that if the problem were not solved, the sergeant probably would have the officer transferred.

D. The Incidence and Significance of Police Perjury in the Chicago Narcotics Courts

Critics of the exclusionary rule maintain that police perjury neutralizes the effectiveness of the exclusionary rule in practice. ${ }^{125}$ They argue both that police can deceive judges with convincing probable cause stories ${ }^{126}$ and that judges often "wink" at perjury in order to permit the convictions of guilty defendents. ${ }^{127}$

To probe the validity of this criticism, officers were asked if they knew of any case in which a judge had disbelieved police testimony at a suppression hearing. Nineteen of the twenty-two officers responding (86 percent) reported that such disbelief was "unusual but not rare." Two officers responded that judges "commonly" disbelieved police officers, and one officer said judges "never" disbelieved police testimony. ${ }^{128}$ When asked about the types of cases in which judges did not trust police testimony, the officers reported that they were almost universally warrantless searches-particularly searches in "on view" and "drop cases."

Ten of the officers (48 percent of the officers responding) believed that the judges were "frequently" correct in disbelieving po-

${ }^{123}$ Oaks, 37 U. Chi. L. Rev. at 739-41 (cited in note 5); Spiotto, 2 J. Legal Stud. at 27576 (cited in note 5).

${ }^{128}$ Oaks, 37 U. Chi. L. Rev. at 730-32.

${ }^{227}$ See Horowitz, The Courts and Social Policy at 252 (cited in note 36).

${ }^{228}$ Question 68 asked: Do you knou of any case in which a judge has disbelieved police testimony at a suppression hearing?

ARE SUCH CASES:

a. Exceedingly rare

b. Unusual but not rare

c. Common

d. Other-"does not occur"

e. No response

\section{OFFICERS}

0

$19(86 \%)$

2 (9ci)

$1(5 ; i)$

$4(0 \%)$ 
lice testimony. No officer stated that the judges were never correct to disbelieve police testimony. ${ }^{129}$ Sixteen of twenty-one responding officers (76 percent), ${ }^{130}$ moreover, agreed that the police do "shade the facts a little (or a lot) to establish probable cause when there may not have been probable cause in fact." Only five officers said they did not believe that officers lied in court, and nine of sixteen responding officers (56 percent) reported that the police lied "infrequently" at suppression hearings. Three of these officers (19 percent) believed that it was "reasonably common" for officers to lie at such proceedings. ${ }^{131}$

Several of the officers, however, reported that police perjury was no longer as frequent as it once was. Two institutional reforms have made it more difficult for officers to lie in court. First, in the Chicago courts, officers are limited in their testimony to information contained in their case reports. Second, the vast majority of

${ }^{128}$ Question 68(b) asked: How often are the judges right in disbelieving police testimony?

\section{RESPONSE}

a. Never

b. Infrequently

c. Frequently

d. Between (a) and (b)

e. No response

\section{OFFICERS}

0

$8(38 \%)$

$10(48 \%)$

$1(5 \%)$

$1(5 \%)$

${ }^{130}$ Officers $10,12,18,20$ and 24 did not respond to this question. In cross-checking, however, Officers 10 and 12 had said in response to Question 69(b) that they believed judges to be correct in disbelieving police testimony "infrequently," while Officers 18 and 24 thought judges were "frequently" correct in disbelieving police testimony. Officer 20 refused to answer the question. Adjusting the statistics for this inconsistency, it appears that twenty-one of the twenty-two officers responding admitted in one way or another that officers do lie or "shade the facts" in court in order to establish probable cause.

${ }^{131}$ Question 69 asked: In your experience, do police officers ever shade the facts a little (or a lot) to establish probable cause when there may not have been probable cause in fact?

\section{RESPONSE}

Yes

No

IF SO, IS THIS CONDUCT:
a. Exceedingly rare
b. Infrequent
c. Between (a) and (b)
d. Reasonably common
e. Don't know

\section{OFFICERS}

$16(76 \%)$

$5(24 \%)$

\section{OFFICERS}
$1(6 \%)$
$9(56 \%)$
$2(13 \%)$
$3(19 \%)$
$1(6 \%)$ 
the searches occur pursuant to warrants that are subject to careful scrutiny by assistant state's attorneys. While neither measure makes it impossible to lie, both make lying considerably more difficult. Finally, many of the officers commented that lying, even in relation to small cases, was not worth the time and effort and the potential abuse from a judge who concluded that the officer was lying.

Nevertheless, police perjury remains a problem in the Chicago narcotics courts. Virtually all of the officers admit that the police commit perjury, if infrequently, at suppression hearings. And given the tendency of questions like those in this study to elicit self-serving responses, it is possible that the frequency of police lying in court is greater than the police admit.

At the same time, however, it is also clear that officers believe that judges independently and aggressively evaluate police officer testimony at suppression hearings. Thus, judicial scrutiny, together with the other institutional reforms noted in this comment, appear to yield significant, if imperfect, control over police perjury.

\section{Police Perceptions of the Effect of the Exclusionary RUle aND THE RULE's Alternatives}

When asked whether the exclusionary rule should be kept as is, scrapped, modified to include an across-the-board "good faith" exception, or modified in some other way, all of the officers responded that the rule should be preserved with a good faith exception. Many of them remarked that the rule was necessary as a limit on police behavior. One officer explained:

I believe in the principle of the exclusionary rule. Sometimes I don't like how judges interpret it. Without the exclusionary rule, police investigating a murder or something would be like a criminal released into the midst of society. They would abuse it. I don't want the rule eliminated, I just want the right to do my job and to prove my cases without being sued. I agree with the rule. It shouldn't be abolished. Society shouldn't be left without the rule.

\section{Officer 26 noted:}

If you abolished the exclusionary rule you would be turning the police department loose. It would be like a military state of some sort. That situation has enormous possibility for abuse. We could just be pulling a gun, putting it to the side of your head and ask, "Did you pay your income taxes?" 
And Lieutenant Karczewski, the head of Special Enforcement, commented:

Of course there has to be an exclusionary rule. I don't want this to be a police state. There have to be guidelines. The problem is that the guidelines aren't clear. I believe that the Supreme Court is not making the law clear. They take a tough situation in which a police officer must act in an instant, they think about it for five months and come out seven to six. What kind of a system is that for making the law?

Several officers said they appreciated the rule because it gave them a reason, within their peer group, to act properly. One officer contrasted today's police conduct with that of the past: "In the old days if we knew something was in the house. . .we would just knock down the door. Now we use a search warrant."

When asked what they meant by a "good faith exception," many of the officers indicated they believed that any good faith exception should involve fairly stringent requirements. Officer 9 suggested, "By good faith, I mean after the search has been discussed and approved by superiors." Officer 10 added, "By good faith, I mean they should examine the thing on a case-by-case basis. There shouldn't be any big rules. They should see whether it is believable that the officer thought he was doing things right. Good faith otherwise is just too broad. I mean, the officer could say anything was good faith, right?" Officer 19 noted, "I don't like the fact that the reason a lot of cases are thrown out is technicalities. But pure good faith is too much room to give a policeman. They should weigh the evidence carefully to see whether the officer should have made that mistake." Officer 27 answered, "It should depend on the officer's past experience. Good faith is minimal. Not just good faith, but good faith in the context of the officer's past experience-in terms of what a reasonable officer should have known." Finally, Officer 30 outlined a good faith exception that was really no exception at all: "The officer may be totally wrong when he is acting in good faith. He may think he is doing something right. It may not be right, just because he thinks it's right. No evidence should be admitted unless you have probable cause. There are a lot of young aggressive officers out there who would abuse the standard."

In response to the question, "How often, if at all, does the law of search and seizure keep you from making the searches that you should be able to make?", 45 percent of the officers answered "infrequently or never," 27 percent answered "frequently," and 18 
percent answered "reasonably often." One officer answered "in-between reasonably often and frequently." One officer said "very frequently."

The officers noted two particular types of searches the exclusionary rule was likely to impede: searches based on instinct and searches when time was too short to acquire a warrant (particularly searches in the middle of the night when judges are not readily available).

When asked how much damage the exclusionary rule does to police work, 33 percent of the officers responded that it did "little if any harm," 50 percent felt it did a "moderate amount," and 17 percent felt the rule did a "great deal" of harm to police work. In particular, some of the officers complained that the rule tends to slow them down in their duties, and that it releases guilty defendants. Several of the officers who maintained that the exclusionary rule did "little if any" or "moderate" harm responded by saying that if the stop or search was illegal, they did not feel anything was lost. Several officers carefully pointed out that the suppression of evidence did not block further police action, and that it often led them to be more persistent in pursuit of a particular suspect.

The officers also were asked if they thought a "system in which victims of improper searches could sue police officers directly would be better than the exclusionary rule." All of the officers responded "no." This question was followed up by asking the officers, "What would be the effect of civil suits for damages on police work?" Twenty-one of the officers (95 percent) responded that police would be afraid to conduct the searches they should make.

Many of the officers' responses were accompanied by explanations. Officer 4 asked, "Why should we do any work if we're going to get sued?" Officer 5 stated, "It would have an inhibiting effect. I get paid the same whether I do it or don't do it. So why put it out on the line?" Officer 6 stated, "We wouldn't do anything. A suit like that would take away my children's college. It's like they are trying to get the officer. It just isn't right." Officer 7 noted, "It would have a demoralizing effect throughout the system. Everybody would be afraid to make the necessary stops." Officer 14, "Why should you do searches if you are going to be sued for doing your job?" Officer 15 stated, "When cops start getting sued for doing their jobs, we will stop acting out of the public good and act out of our own good." Officer 24 stated, "I would be reluctant to pursue or search someone, unless I was 100 percent certain. I would still be reluctant. I don't want to be sued civilly. My per- 
sonal finances should have nothing to do with what I do at work. I should have sufficient protection for what I do at work when I am doing my job in good faith." Officer 30 stated, "Would you want to be sued? It would absolutely throw the monkey wrench in everything around here. Nothing would happen." Finally, Officer 10 stated, "I have to put up with a lot of shit to do my job, and if I go through all of this and they say to me, 'you are liable.' My God. I make less than the judges and attorneys. I have a family. I have to make decisions. But if every time you have to make a judgment, you have to think of 'you and yours.' I will do my job to the best of my ability. I can't be sued."

\section{Conclusion}

The exclusionary rule is by no means a costless or perfect remedy for fourth amendment violations, but in the Narcotics Section of the Chicago Police Department it has created a system of incentives for individual officers, reinforced by institutional practices also prompted by the rule, that deters unlawful police searches. While a rigorous quantitative analysis of the rule's effects may never be available, this study suggests that the Supreme Court's skepticism concerning the deterrence rationale is unfounded. According to Commander Ryle and the officers interviewed in this study, adherence to the fourth amendment by individual officers, and the institutional reforms reinforcing that adherence, have been and are likely to remain tied to the exclusionary rule. Moreover, the Court's decision in Leon threatens to undermine the institutional responses to the exclusionary rule and the consistently correct search behavior they have fostered. These reforms were created to make certain that a search warrant was sufficiently grounded in probable cause. Leon may make this elaborate apparatus unnecessary. Some police officials believe that, in the next "era of declining resources," the institutional reforms created in response to the exclusionary rule may be in danger. ${ }^{132}$

This study does identify costs associated with the use of suppression to deter: the police sometimes perjure themselves in suppression hearings, and tend to view the process as a lawyer's game. The suppression mechanism also fails to inhibit some constitutional violations: when officers flout the fourth amendment to get

${ }^{132}$ Ryle Interview, June 6, 1986. Further, because of declining resources, a program designed to train all police tactical officers in writing search warrants ws recently discontinued. Larry Wherrie telephone interview, March 20, 1987. 
contraband off the street (so-called "confiscation searches"), the rule is ineffective.

Still, aggressive judicial scrutiny, coupled with other reforms such as the rule that testimony may not go beyond the case report, have minimized the damage that police perjury can do to the rule. Moreover, it is important to realize that any remedial scheme that imposes a personal sanction on an officer is likely to encourage perjury. Clearly, there is no reason to believe that police officers who lie in order to prevent suppression of evidence will not do so to prevent personal liability in a tort action.

The exclusionary rule has had a pervasive effect on the practices of both the Narcotics Section and on individual Chicago narcotics officers. In the end, these events reinforce the notion that institutions and individuals sometimes take time to respond to major systemic changes, but that they can eventually respond in creative and effective ways.

Myron W. Orfield, Jr. 


\section{APPENDIX}

Question 25: How generally would you characterize the attitude of your superiors when evidence is suppressed because of an improper search?

Officer 5: If they saw a problem, they would spend time harping on it a lot more. Nobody likes to lose any cases. This is part of the reason we have informal training. This is the reason we keep statistics on lost cases.

Officer 6: They are concerned that things aren't being done properly.

Officer 7: They are concerned about convictions. It is a more significant concern if it is a multi-ounce or multi-pound case.

Officer 8: They try to correct whatever is wrong. They are concerned.

Officer 9: I wouldn't say they are angry, their concern is to build better cases.

Officer 10: Their reaction? They look at the facts involved in the case. If they feel something is wrong, they would advise you. They are concerned to see if the officer was acting in good faith.

Officer 12: They are concerned and point out what we did wrong if it is obvious.

Officer 13: They are concerned. They like convictions.

Officer 14: They are concerned. It's a job. Everyone is concerned. But it's just a job. They just want you to do it better.

Officer 16: They are understanding about it.

Officer 17: They are concerned. The bosses want narcotics convictions. They know what type of things happen on the street. They are pretty helpful. But don't let it happen again. When they review things with you there is a firm format. They want you to do something constructive with the experience, to learn something from it.

Officer 20: They talk to you about it. They ask you why. If you do a bad search warrant on a house. . . . People don't like evidence suppressed around here.

Officer 21: It varies from superior to superior. Some superiors are very concerned; others take it in stride.

Officer 24: They are always concerned to find out why. And if we can't find out why, they will go out of their way to find out why. They are very concerned.

Officer 25: They are very concerned about it here. In this place, they want convictions. I'll venture a guess that if next year you had a high production rate and a low conviction rate, they 
would whistle you out of here. You will go someplace else. They are concerned about convictions. They are concerned about putting people out of business.

Officer 27: After something is suppressed you go in and you explain it, then you break it down one more time. You go over it and over it. Also every time you draft a complaint for a search warrant, the lieutenant and the state's attorney sign every page.

Officer 28: They ask you what happened. They say stuff like "Didn't you know that?" They make sure you don't make the same mistake twice. They keep a record of the cases that we win and lose.

Officer 29: They know the game. They know what they're doing. The sergeant is there all the time. Prior to the search, he signs all the case reports, if he is likely to say something he will say it before.

Question 26: Do your superiors react differently when you have evidence suppressed in connection with a "multiounce' or 'multi-pound' case and if so, how?

Officer 4: Occasionally. They question why.

Officer 5: Probably, this is a working office.

Officer 6: It's only human nature. They are more likely to talk to you.

Officer 7: Yes.

Officer 8: In connection with a big bust, they become very angry and they reprimand you.

Officer 9: They interview you to find out why. A lot of the time, it's not our fault. It is the fault of the state's attorney. This is because the lower courts are so overworked. The state's attorneys are so overworked. As soon as the state's attorneys start to be proficient, they could go into private practice. A lot of coppers know more about the law in this area than the state's attorney does. There is a lot of paperwork to fill out when evidence is suppressed.

Officer 10: Definitely. They pay more attention to a multipound case. They look at the work involved in multi-pound. A multi-pound case is usually much closer to the S.O.S. [source of supply]. They want to make it work. There is more work into a multi-pound case.

Officer 11: Yes, they are more likely to go over it with the officer.

Officer 12: Yes, they go over the case more carefully.

Officer 13: Yes, they are very concerned. Police officers don't like it when evidence is suppressed. 
Officer 14: If it is a big case your superiors express more interest. They probe as to why.

Officer 16: Yes. It is not a disciplinary action. You go over the case with your supervisor. Your immediate superior is more knowledgeable. The only time the lieutenant or Commander will talk to you is in terms of a real significant search-like a kilo.

Officer 17: Multi-ounce, multi-pound. You fuck up on a big case and you hear about it.

Officer 18: Yes, they are concerned about all cases, but they are more concerned about big ones. They look at what the reasons were. They make sure it doesn't happen again.

Officer 19: They go over the facts of the case with you.

Officer 20: They read the court attendance reports and they spot the problems in the dispositions.

Officer 21: Same [referring to his answer to Question 25 above].

Officer 22: Yes, they want to win. They go over it more carefully.

Officer 23: Yes.

Officer 24: It's different. These cases are all important. They go over it more carefully.

Officer 25: They are more concerned. With a multi-ounce case, they have spent a lot of money. There is a lot of time lost in a case like that. If it is something you did wrong, you are set down and talked to. "Why did this happen?," they ask. "I didn't know what I was doing," I say. If it was a simple mistake, they ask, "Why?" They will whistle you out of here-the first time, maybe. You lose two big ones and you are out.

Officer 27: There is more reaction to a large seizure. The guys on State Street [central police headquarters] are not too happy. If it is a search warrant, they are pissed. If it is a buy bust, they say, "You have spent our money." In these things, you spend real money. I had a thunder roll of $\$ 23$ million. Although this was a bargain basement price for what I got. I got 95 defendants and 200 plus buys on that $\$ 23$ million. You don't want money circulating on the streets. You buy drugs and weapons-griefs. You do a multi-ounce search warrant and you have kind of a quicky pretrial meeting. Everything is figured out pre-raid in the buy bust-the signals you will be giving, etc. If this takes place, you make sure everything is in order. Nobody wants to look like an asshole on the stand.

Officer 28: Yes, they don't want to see you lose a case. They ask, "Don't you have a good case?" You have to put down the rea- 
sons why you lost it on the sheet or else they will kick it back to you.

\section{Police Accounts of Suppression of Evidence}

The following are transcribed "shorthand" notes of police accounts of their experiences with the suppression of evidence in the period roughly between March 1, 1985 and June 1, 1986.

Case One: Officer 4, a detective in SEN, reported two suppressions.

Officer 4: I observed a subject who appeared to be delivering a quantity of narcotics to another individual. Basically, it was a hand-to-hand delivery. I had done a search warrant on his house prior to this. It didn't turn anything up. I was in the process of getting another warrant.

I was observing this individual-following him-and I saw him take a box out to his car and put it behind the driver's seat. I followed him. I observed him stop his car and approach another individual. This other individual slipped something to the suspect, and the suspect gave him the box. I subsequently stopped the suspect and the guy that received the package. The box was filled with a large quantity of cocaine. I arrested both the subject and the other individual. Then the judge threw out the evidence.

Interviewer: Why did the judge throw it out?

Officer 4: The judge threw it out because he said I never saw the cocaine before I stopped the guy. My truck was a block or two away from the transaction while it was occurring. I observed the deal from a block or two away, and he said that was too far. I explained that I was right behind this guy, following him. That I saw the subject carry the box from his house and put it right behind him-behind the drivers seat. I had observed him with the box.

Case Two:

Officer 4: We had information on this subject doing business out of a motel on the North Side. We had a search warrant for his motel room. He was dealing cocaine out of that room. The information came from a reliable informant. We staked out the motel. We observed the suspect coming out of his room-we knew which room he was in-and saw him walk over to a tree. We then observed him pick up a bag underneath a bush. He then got in a vehicle and drove away. We stopped him and observed the bag through the window and arrested him. The judge threw out the evidence.

Interviewer: Why? 
Officer 4: The judge didn't believe us. He said there was no probable cause for the search.

Case Three: Officer 9 was a police officer in SEN at the time of the reported incident. He was later transferred to GEN.

Officer 9: It was a job in the Diversion Squad in conjunction with the DEA Compliance Squad, the Illinois State Police, Division of Criminal Investigation, Criminal Fraud Unit, and the Illinois Department of Reg. Ed. We all share info and work as a minitask force. There is really a wealth of information between us.

We received information on a suspected druggist, because of his ordering habits for codeine syrup and high-volume clientele, of a pattern of clandestine order and pickup of codeine-based syrup. CPD and DCI [Chicago Police Department and Illinois State Police, Division of Criminal Investigation, Criminal Fraud Unit, respectively] followed this individual to Glasgow, Kentucky. We watched him load 64 gallons of [codeine] syrup into his private vehicles. The gallons were in bottles-four to a case. We followed him back to Chicago, and we actually saw him take the gallon bottles out of the cases and put them into paper bags. He put them into shopping bags-two gallons in each shopping bag. He put the cartons in dumpsters along the roadway-at fast food places when he would stop to eat or something. We collected these boxes as evidence. . . . He arrived at his house and we set up a fixed surveillance. We had a search warrant for his house, garage, and vehicle in the works. I think that somebody was typing it up. The Assistant Attorney General of Illinois was in on this, so was DCI and the FBI. Suddenly the garage door opened and the suspect drove out in his personal vehicle-a Dodge Caravan. It had open windows. We had watched this guy repackage the stuff, watched him help loading the syrup into his van. We had followed him up 400 miles. We were in constant radio contact with each other. When he drove out, one of our cars in the fixed surveillance had just broken off to get food. So the remaining car followed this guy, and we started calling for assistance. The man was taking a circuitous route-left turn, right turn. We stopped him. We IDed ourselves and asked him to step out of the car. As he was being spoken to, we looked inside, through an open window in the van, and saw all the repackaged syrup. He was not going anywhere near his legitimate drug store. We had a right to do what we did. The route was nowhere near his pharmacy. This was a controlled substance. We seized the contraband and the vehicle. We said the stop was based on "exigent circumstances." The judge found that there was probable cause at the preliminary hearing, but the evidence was thrown 
out in trial. The judge said the stop was based on "insufficient evidence" and that there was no probable cause. Also, the judge thought this guy was a pharmacist, he could legally buy all this cough syrup and that he was just putting it into the bags to make it easier to carry.

My own personal opinion is that the case was thrown out because it had problems of all diversion cases. The state's attorneys are unwilling to prosecute these cases and the judges are unwilling to convict-because diversion is so new. Being a lawyer is an upper-middle class profession. So is being a pharmacist ... . [the judges] just don't want to believe these types of people-people like them-are doing this terrible thing. Also the judge liked the defense attorney. I think we could have had this guy if this case was prosecuted correctly.

Case Three (second account of the same search): Officer 10 was a detective in SEN.

Officer 10: We were doing an investigation. It went down about a year ago. It was a long-term investigation. There was this pharmacist who was going out of state to buy large quantities of codeine syrup. At this particular time we observed him buying 64 gallons. He paid in cash. He transported the stuff from Glasgow, Kentucky, to his home in his private car. He brought it to his house. He had his wife driving, and along the road, he was taking the codeine syrup out of the cartons and disposing of the cartons in trash containers. He put the syrup in shopping bags-two gallons to a bag. When somebody was getting food, he took off. $\mathrm{He}$ must have suspected something, and we followed him and arrested him. We said the search was necessitated by "exigent circumstances." He wasn't going anywhere near the pharmacy and was zig-zagging all over the place. The evidence was suppressed because we didn't have probable cause for the stop. But even if it wasn't suppressed, the case was a loser. The judge felt that as a pharmacist he was entitled to get cough syrup and the reason he placed the stuff in the bags was because it made it easier to carry.

Case Four: Officer 14 was a police officer in GEN.

Officer 14: The case involved a street stop. I knew the guy. I know that he was dealing. The judge said there was no probable cause. It had to do with the way I said "reached." I testified that he "reached" into his pants pocket, and then I searched him. I should have said something like, "He reached into his pocket in an unusual manner as if to get a gun or something"-but I didn't. I just said he "reached into his pants pocket." I searched him, and I found some drugs on him. The judge threw it out. He didn't think 
"reaching" into his pants pockets was suspicious enough for even a protective search and didn't think a frisk would have turned up any marijuana. I could have said something like there was a hard clumpy bag, but I didn't.

Case Five: Officer 17 was a detective in GEN.

Officer 17: It was last week. We had a search warrant for the rear room of a barber shop. We found a brief case full of heroin. ... We found the briefcase outside the scope of the search warrant. The search warrant was for the rear room. The briefcase was just outside the door of the rear room. It was in the back room. .. . The back room was simply not within the scope of the warrant. We found paraphernalia in the rear room, but no actual contraband. We could have opened the briefcase or put it in the rear room and not just leave it there. We wouldn't have lost in court. Actually, I'm surprised it got past the preliminary hearing.

Case Six: Officer 18 was a detective in GEN.

Officer 18: It was a search warrant case. Evidence was recovered outside of the location where the search warrant was for. The search warrant was for a first-floor apartment, we found the stuff outside in the yard by the garage. It was narcotics and marijuana. While searching the apartment, I saw someone run out of the apartment and through the backyard. . . . I saw the person toss a large plastic bag by the garage. That was it. The judge said the warrant was for the first-floor apartment only and we didn't have probable cause for a yard search, when nothing was found in the first-floor apartment. He didn't believe the story about the person running through the yard. But even if the search was okay, there probably would have been a constructive possession problem, tying the resident of the apartment to the stuff we found in the backyard.

Case Seven: Officer 24 was a police officer in SEN.

Officer 24: $\mathrm{Me}$ and my partner were doing surveillance on a particular house. People come up to the house and go in to the house and then come out. As these people were coming out of the house they took off real quick. They blew a stop sign and then took a turn without a signal. "Good," we said, we had a reason to stop them. So we stop them. As we were coming up to them, we saw this guy, the driver reach over across the seat and hand something to this woman who was sitting next to him. When we get up to the car, we see this plastic bag sticking out of the zipper of her pants. I search her and in the plastic bag, there is heroin. We go to court. We had a legitimate stop and a reason for being there. But this judge just can't believe our story. A bag sticking out of this lady's 
pants. He just doesn't believe it. He thought there was some sexual harassment involved. My partner was testifying at the trial. $\mathrm{He}$ told the state's attorney that I was a female. But the state's attorney didn't say anything. It was a woman state's attorney. It was a stupid mistake, I thought. The judge suppressed the evidence, he said there was not probable cause. He said that in the search for a weapon, we wouldn't have felt a package of heroin. He made some remark about we should be looking for a gun. Apparently, he didn't believe that the bag stuck out. It was a very light explanation, and I wouldn't be surprised if it was a crooked deal.

Case Eight: Officer 25 was a police officer in SEN.

Officer 25: It was a buy-bust situation where the arrestee [the officer used the term "arrestee" for the confidential informant who made the buy] had gone to another location. Usually, you watch them buy something on the street and then bring the stuff back to the buy officer. We went into the location without a search warrant. We had 850 dollars into this place. We thought we had exigent circumstances. The judge said that there was not exigent circumstances and ruled the evidence was improperly confiscated and suppressed it. The judge felt that we had enough time to contain the premises without doing a warrantless search. The bad guy and arrestee went into this house and the undercover officer followed them. He went into the house to get the contraband. He [the informant] just went into that house. We didn't know he would. $\mathrm{He}$ went in there with the guy he got it from. It takes time to get a warrant. It takes two hours. This was 6:00 p.m. and it was a bad time to try to find a judge at court. It would be eight or eightthirty before the warrant would come. Nine o'clock p.m. is late at night. They don't like it when you search a house at night.

Case Nine: Officer 28 was a police officer in SEN.

Officer 28: This CI [confidential informant] went to a location to do a buy. He informed me that there was drug activity going on at a certain address. I took his word for the address and typed that address on my search warrant. When I got back to the location, I did the search and found the stuff. I didn't realize that there were two different addresses at the location, and the place I searched didn't have the same address as the warrant did. The evidence got tossed out because of the bad address.

Question 22: What particular rules or lessons have you learned from having evidence suppressed?

1. General substantive law of search and seizure:

Officer 3: Yea, as a young cop, I learned that I'd better have a 
good reason before I search a car. I'd better have more than just "apparent drunkenness."

Officer 4: I learned that the vast majority of your on view cases are losers.

Officer 8: Before stopping people in neighborhoods at a late hour, you better have a good reason. Just late hours is never enough. I used to think that saying "late hours" was enough.

Officer 9: I learned about "fruit of the forbidden tree." By the law if it is an illegal stop, therefore all evidence that came in any way from that stop is illegal and can't be used by the patrolman.

Officer 12: The lesson? Basically, the law of search and seizure is common sense. That's all it is. Search warrants are different, but they are supervised. For an on view all you need is enough probable cause.

Officer 13: When somebody drops a bag, you look at it closely before you search the perp [perpetrator].

Officer 18: Specifically, I've learned about street stops. We make sure we have probable cause to make a street stop before we do it.

Officer 20: I learned something about when you have immediate information and no time for a warrant. A year ago, I went into somebody's house. In homicide, you could say personal injury was at stake in a situation like this. I learned that this doesn't apply to narcotics.

Officer 22: About 50 percent of on views are losers.

Officer 24: You do a questionable street stop and nothing holds. It gets tossed out. The lesson? You can't be too careful. Last time I didn't anticipate losing in court. I still don't understand why.

Officer 25: This is the same case where stuff got suppressed. We thought we had exigent circumstances. The next time we will secure the place and get a warrant. You know, in this business it really depends on how bad you want the guy. Basically a lot of these guys are users. The dealers are the guys we really want. The dealers are using people. Like if you are doing the Herraras [referring to the Herrara family, a group that reputedly imports cocaine from Colombia], it might take six months, eight months, maybe a year. But if you did it right, you could get them. You just have to make sure you got everything correct. Most dope dealers are clever people. . . .

Officer 28: I learned that you shouldn't do a buy bust without a warrant. Now I type up a warrant and then I have a buy as well as the possibility of doing a search warrant. I can get him two- 
handed. . . . I don't come up empty-handed that way.

Officer 29: It is always the stronger case doing a search warrant. Get the gun in the apartment when you arrest the guy as opposed to issuing an arrest warrant and doing the search warrant later. It's a lot tighter this way. If you get him and at the same time find dope and scales, that's better.

2. Practical operation of fourth amendment rules in the judicial system:

Officer 5: Even though I feel I understand the law and the rules of evidence, the real lessons in this whole thing have to do with experience of the judicial system - to see what things are really like in court. It is easy to read about what probable cause is, but you don't know the reality of probable cause until you get to court. When you are in court, you find out what gets past the judge and what doesn't.

Officer 17: You learn that different things are treated differently [in court]. It depends on the judge's perception. One judge might think something is important, another won't. You learn that good lawyers make a lot of difference and can make things seem different than they really are. You learn that you are tied to a specific format, the case report. Everything-where it is, who found it-everything-where on the scene the stuff was, who found it. The format is so exact. . . .

I learned that you should make it up to the judge. Even if you know it's going to get tossed, get the guns, get the junk, and let the judge decide to put these people on the street. You give him the decision. To leave the people on the street is wrong. You get the guns always, because if you leave them out on the street, the next time a policeman does a warrant, he'll get shot.

Officer 18: You go to court. That's the most important. You see what happens, what technicalities cause what. Going to court is more concrete than training. It is on-the-job training, and like onthe-job-training it is the most useful way of learning. It gets you into the actual situations. It gives you a certain knowledge of what will be suppressed. It tells you what to do, and you go out and do it.

3. The need for specificity in making out case reports:

Officer 3: I also learned to carefully list my observations on the police report.

Officer 14: Narcotics is totally different from anything you got going. Because they tell you-they tell you to show it on paper. It's all theory. If you don't, you lost the dope. Take any policeman, watch and listen to him in court all the time. It is not rated ... 
not on you or on the job you do to the best of your ability. In court you can't use plain words. You use words that you have to pick and choose to get the same meaning across. If you explain the way you did it-you might lose it. Some words carry more meaning. If I find dope on a person, I say, "I found clear white powder in right rear pocket," you see to describe the dope. You have to be clear in what you say, in describing what it was. You say "on his person." What is dope? You got to specify. You have to know what to say. You have to know about appearance.

Officer 15: I learned to elaborate more on my reports-how to make the wording so it looks convincing in court. You see a black guy in a new car in a suburban neighborhood, you say something like "it was an all-white neighborhood and the defendant was black and perhaps he was driving a stolen car." You have to give more background.

Officer 18: In terms of a search warrant, you list exactly what the search will contribute. You record the contraband. We want specifics in case reports. You have to be even more specific than in warrants.

Question 20: When evidence in a case that you have been working on is suppressed, what are your usual reactions?

Officer 4: It depends on the case. If it is a large quantity, then I am upset. If it is two or three sticks of marijuana, I don't get crazy. If it is a large quantity, I question why. In a large case, they give more weight to the statement of the officer.

Officer 5: It depends on the circumstances. If I feel my decision was right, I am frustrated. Most of the time I don't get personally involved. I do my job, it's up to them [referring to the judge, the defense attorney, and the prosecutor] to do theirs.

Officer 6: I feel I have no control over it.

Officer 7: I never get angry or frustrated. Anybody who gets frustrated is foolish. You just do what you have to do.

Officer 8: The judge explains why. . . . It is part of the job.

Officer 10: I am analytical. I ask, "What can I learn from it? Should it really have been suppressed? What do I do about it in the future?" It is a learning experience. It does me no good to beat my head against the wall.

Officer 12: It happens very rarely.

Officer 14: It's just part of the job.

Officer 15: I am disappointed.

Officer 17: I know beforehand. I am not surprised. When I lose a case I find out why it was excluded. I used to get angry, but not 
any more. The guy gets caught in the end anyway.

Officer 18: I am disappointed. I don't like to lose a case on a technicality. It bothers you. I don't like to see a drug dealer go on a technicality.

Officer 19: That's life.

Officer 22: It depends on the case and how hard you worked on it. You take extra precautions and make sure it is not thrown out if you care about the case.

Officer 24: I ask why.

Officer 25: I used to get mad in the early days. They would be thirty-six hour days and then you'd have to go to court. Now I never get mad. Now, chances are that it will very seldom happen, 1 percent to 2 percent of the time. The judges didn't use to explain why things would be thrown out.

Officer 27: I'm not terribly pissed off. I kick myself in the ass. I demand something for an explanation. Sometimes it is a new learning experience. You give them the facts and let the state's attorney allow you to bring it out.

Officer 28: I don't take it personally. It is just something you did wrong. If the person is still involved in it, you will eventually get him anyway.

Officer 29: I get pissed off. Pretty good case, really no time factor. No one is pushing you. You ring and show your search warrant. Those guys pay their lawyers a lot of money. The judge is not 100 percent. I've been in trial, somebody says, "Delivery for ." In a delivery trial, they would normally find the guy guilty. Then there is a motion to fix. This happens in bench trials, otherwise they're not able. It happens 5 percent of the time or more.

Question 28: Could the continued loss of evidence to improper search and seizure techniques affect, in any way, an officer's ability to ... (b) qualify for a promotion?

Officer 5: It could affect performance rating and might ultimately affect your ability to get a promotion.

Officer 6: Yes, it depends.

Officer 8: It would certainly blacken a person's record. Promotions are based on a test, but also on your efficiency rating. Even if the test results were positive, there would still be an efficiency problem.

Officer 15: It should, but I don't know.

Officer 16: Maybe.

Officer 29: Yes, you would be reassigned. 
Question 32: How else could a pattern of repeatedly having evidence suppressed effect the reputation of a police officer?

Officer 3: You get every case thrown out and your credibility would go down.

Officer 4: I doubt it. It just doesn't happen that often.

Officer 5: It would ultimately injure your reputation as a professional. It would indicate a lack of proper training or work ethic.

Officer 8: It would indicate that the officer is not doing his job. That he is struggling in his job.

Officer 10: It would indicate that the officer is not competent.

Officer 11: It would indicate that the officer is an idiot and an incompetent. No one would want him around.

Officer 12: If the officer were constantly losing evidence, people will not work with the officer. The warrant will be scrutinized before it is approved by the state's attorney very carefully.

Officer 13: Let's take the steps of a search warrant. You type it up. The sergeant reads it and signs it. There is Felony Review. The state's attorney approves it and signs it. The judge does the whole thing one more time. It can take two hours to fifteen hours. If you are out of the district, you notify the watch commander and he wants to know what you are doing. Now five supervisors have gone over it.

Officer 14: It means that the officer hasn't learned a thing and that he has poor work habits.

Officer 15: The officer would be under suspicion. It might be thought that he is collaborating with the defense. That is my opinion.

Officer 21: They would think the officer was crooked.

Officer 22: The officer's peers would think he was stupid.

Officer 24: People would not want to work with the officer. All of them would know something is wrong.

Officer 29: The wording of the case reports is important. You have a good warrant before the judge ever sees it. You have a good solid warrant before the judge reads it the first time. You decide to do a search warrant. You do your homework. The informant sees it. Then you do buys or check it out yourself.

Question 29: Could a pattern of repeatedly having evidence suppressed affect an officer's [working relationship with his] sergeant?

Officer 5: Yes. If the sergeant felt I was short on my inventory 
or that I was circumventing the system. If he felt I wasn't conducting evidence properly enough and resorting to hit-and-miss and on views, he would be reluctant to give me complicated assignments. Yes, you must handle the evidence properly.

Officer 6: They will get rid of you.

Officer 7: If the sergeant saw the officer doing the same thing over and over again, he's not going to let him do that.

Officer 8: He'll think your searching is bad.

Officer 9: He would not trust the guy involved in the case.

Officer 10: It is obvious that the officer isn't learning from past experiences and obviously he's not capable of making a good case.

Officer 12: I don't think so. He [the officer] would be given extra training or moved to a different assignment.

Officer 14: He will watch your work patterns. If he sees anything wrong, he will correct you.

Officer 16: Yes, you'll just be gone.

Officer 18: The sergeant would be concerned with what the officer is doing wrong - that all the evidence is being suppressed. He would talk to him about it.

Officer 21: The sergeant would counsel and talk to the individual. If this wasn't enough, he would take steps for a disciplinary action, reprimand, or suspension. I am speculating because these sorts of things don't happen here.

Officer 22: It could if the sergeant gets pissed.

Officer 24: The sergeant wants to know why. He is concerned. Even if it is only one case, he wants to know why.

Officer 25: Everything they do, he'll question them on. The guy's working for you. He might think the guy is crooked. It depends on the sergeant's attitude and the type of case lost. There is not always a presumption of being crooked.

Officer 27: They are tickled pink.

Officer 28: Yes, I think so, but I'm not sure. I'm not here long enough to see a pattern.

Officer 29: He wants a conviction rate of 100 percent. He will want you to be sure of having conviction before you do it. He signs the case report. He will want more thoroughness in a complicated case. 